ARTICLE

DOI: $10.1038 / s 41467-017-00414-w$

\title{
Exploiting a novel conformational switch to control innate immunity mediated by complement protein $\mathrm{C} 3 \mathrm{a}$
}

Rink-Jan Lohman 1,2,3, Johan K. Hamidon 1,3, Robert C. Reid (10 1,2,3, Jessica A. Rowley 1,2,3, Mei-Kwan Yau1,3, Maria A. Halili ${ }^{1,3}$, Daniel S. Nielsen 1,3, Junxian Lim (10 1,2,3, Kai-Chen Wu1,2,3, Zhixuan Loh²,3, Anh Do1,2,3, Jacky Y. Suen ${ }^{1,2,3}$, Abishek lyer ${ }^{1,2,3} \&$ David P. Fairlie ${ }^{1,2,3}$

Complement $\mathrm{C} 3 \mathrm{a}$ is an important protein in innate and adaptive immunity, but its specific roles in vivo remain uncertain because C3a degrades rapidly to form the C3a-desArg protein, which does not bind to the C3a receptor and is indistinguishable from C3a using antibodies. Here we develop the most potent, stable and highly selective small molecule modulators of $\mathrm{C} 3 a$ receptor, using a heterocyclic hinge to switch between agonist and antagonist ligand conformations. This enables characterization of C3 areceptor-selective pro- vs. anti-inflammatory actions in human mast cells and macrophages, and in rats. A C3a receptor-selective agonist induces acute rat paw inflammation by first degranulating mast cells before activating macrophages and neutrophils. An orally administered C3a receptor-selective antagonist inhibits mast cell degranulation, thereby blocking recruitment and activation of macrophages and neutrophils, expression of inflammatory mediators and inflammation in a rat paw edema model. These novel tools reveal the mechanism of C3a-induced inflammation and provide new insights to complement-based medicines.

\footnotetext{
${ }^{1}$ Institute for Molecular Bioscience, The University of Queensland, Brisbane QLD 4072, Australia. ${ }^{2}$ Centre for Inflammation and Disease Research, The University of Queensland, Brisbane QLD 4072, Australia. ${ }^{3}$ Australian Research Council Centre of Excellence in Advanced Molecular Imaging, The University of Queensland, Brisbane QLD 4072, Australia. Rink-Jan Lohman, Johan K. Hamidon and Robert C. Reid contributed equally to this work. Correspondence and requests for materials should be addressed to A.I. (email: a.iyer@imb.uq.edu.au) or to D.P.F. (email: d.fairlie@imb.uq.edu.au)
} 
$\mathrm{P}$ rotein-protein interactions (PPIs) mediate most physiological processes and involve large interacting protein surfaces that are proving to be extremely difficult to mimic, or interfere with, using small molecules in vivo ${ }^{1,2}$. Most PPIs are currently thought to be 'undruggable' using conventional small drug-like molecules ${ }^{1-3}$. A significant challenge in chemical biology is to rationally downsize a protein to an equipotent small molecule that could be cheaper to manufacture, easier to structurally and functionally modify, non-immunogenic, and likely more stable and more orally active ${ }^{1,4}$. Complement C3a is a $\sim 9$ $\mathrm{kDa}$ helix bundle inflammatory protein that binds to $\mathrm{a} \sim 100 \mathrm{kDa}$ $\mathrm{G}$ protein-coupled receptor called $\mathrm{C} 3 \mathrm{aR}$ expressed on the cell surface. C3a is thought to be important in mediating inflammatory responses to infection and injury ${ }^{4-6}$. C3a concentrations are reportedly elevated during inflammatory diseases ${ }^{7}$, recombinant C3a reportedly induces hypertension and delayed neutrophilia in rats over $24 \mathrm{~h}^{8}$, while sustained activation of C3aR vs knockouts support a role in allergies 9 , asthma ${ }^{10}$, $\operatorname{arthritis}^{11}$, sepsis ${ }^{12}$, lupus ${ }^{13}$, diabetes $^{14}$, ischemia-reperfusion injury ${ }^{15}$, obesity and metabolic dysfunction ${ }^{16}$. However, the actions of $\mathrm{C} 3 \mathrm{a}$ in vivo remain uncertain because $\mathrm{C} 3 \mathrm{a}$ is synthesized at the cell surface and very rapidly degraded by extracellular carboxypeptidases, which cleave off the C-terminal residue Arg to form C3a des-Arg ${ }^{4-6}$ that does not bind to $\mathrm{C} 3 \mathrm{aR}$ and has a completely different pharmacological profile. Moreover, commercially available antibodies used in many in vivo studies do not discriminate between C3a and C3adesArg ${ }^{7}, 15$. Thus, most claims for detection of C3a in vivo or for properties of exogenous $\mathrm{C} 3 \mathrm{a}$ administered in vivo may be compromised. Synthetic agonists that act through C3aR, but do not degrade rapidly like $\mathrm{C} 3 \mathrm{a}$, could aid the characterization of $\mathrm{C} 3 \mathrm{a}$ biology in vivo and may be valuable immunostimulants or antimicrobial agents ${ }^{17}$, while metabolically stable and orally active antagonists may be valuable new anti-inflammatory agents with therapeutic potential ${ }^{4-6,18}$. No drug-like small molecule agonists or antagonists of $\mathrm{C} 3 \mathrm{aR}$ have been found yet with high potency, selectivity, metabolic stability and oral bioavailability for interrogating $\mathrm{C} 3 \mathrm{a}$-mediated functions in vivo ${ }^{4}$.

Recently, we described an approach to rationally downsizing the 77 residue human complement $\mathrm{C} 3 \mathrm{a}$ protein to small molecule agonists $(\mathrm{MW}<500)$ equivalent in size to just the last 3-4 amino acid residues of the $\mathrm{C}$-terminus of $\mathrm{C} 3 \mathrm{a}^{4}$. These compounds were built from the $\mathrm{C}$-terminal arginine of $\mathrm{C} 3 \mathrm{a}$ and displayed the same capacity in vitro as human $\mathrm{C} 3 \mathrm{a}$ to induce calcium release and the expression of inflammatory cytokines in human macrophages ${ }^{4}$. While C3a is degraded within minutes in plasma, these small molecule proxies for $\mathrm{C} 3 \mathrm{a}$ are stable in plasma and may be useful with some modifications as pharmacological tools to probe $\mathrm{C} 3 \mathrm{a}$ properties in vivo. We have also probed how the relative hydrogen-bonding potential of different heterocycles contributes to binding affinity ${ }^{19}$ and used theoretical calculations to predict barriers to rotation, and hence the probable population of different conformers which was then related to functional activity ${ }^{20}$. Here we have significantly extended that work by incorporating different heterocycles to switch from agonist to antagonist conformations, culminating in the most potent small molecule activators and inhibitors known for the $\mathrm{C} 3 \mathrm{a}$ receptor in vitro and in vivo. We characterize their solution structures, their activities on human mast cells and macrophages, their target specificity, and their effects on $\mathrm{C} 3 \mathrm{a}$-dependent innate immune responses in a rat model of acute inflammation. This is an important advance in (i) identifying the actions of the $\mathrm{C} 3 \mathrm{a}$ protein, which degrades rapidly in biological fluids, (ii) rationally developing small molecule agonists and antagonists of $\mathrm{C} 3 \mathrm{aR}$ for use in vivo in physiology and disease, and (iii) identifying the temporal sequence of cellular immune responses to activation of C3aR in rodents. This novel approach to downsizing a protein to conformationally restricted small molecules may lead to complement-based medicines and encourage similar approaches to modulate other protein-protein interactions.

\section{Results}

Heterocycles switch ligand function on human mast cells. Human complement protein $\mathrm{C} 3 \mathrm{a}$ is known to degranulate mast cells in vitro to release histamine ${ }^{21}$. Here we report (Fig. 1a) a thiazole-containing small molecule $\mathbf{1}(\mathrm{R}=\mathrm{H})$, which is a partial agonist at sub- $\mu \mathrm{M}$ concentrations in inducing histamine release from human LAD2 mast cells (Fig. 1b). Incorporating a 5-methyl substituent $(\mathrm{R}=\mathrm{Me})$ gives the thiazole analogue 2 , which shows a full agonist response (Fig. 1b). Replacing the sulfur atom in $\mathbf{2}$ with an $\mathrm{NH}$, to produce the alternative imidazole heterocycle in compound 3, increases agonist potency by a further log unit, leading to potency comparable to human C3a itself (Fig. 1b). Interestingly, we find that transposing the positions of nitrogen and sulfur atoms in the central thiazole ring of compounds $\mathbf{1}$ and $\mathbf{2}$ to give compounds $\mathbf{4}$ and 5, respectively (Fig. 1a) switches the biological function from agonism (Fig. 1b) to antagonism of C3a-induced histamine secretion (Fig. 1c). Thiazoles 4 and 5 were the most potent $\mathrm{C} 3 \mathrm{a}$ antagonists known, the methylated analogue 5 being slightly less potent. Removal of the thiazole nitrogen atom in 4 gave the thiophene $\mathbf{6}$, which is a 10 -fold more potent antagonist of $\mathrm{C} 3 \mathrm{aR}$ (Fig. 1c). Compounds $\mathbf{3}$ and $\mathbf{6}$ are the most potent small molecule agonists and antagonists reported for the human $\mathrm{C} 3 \mathrm{a}$ receptor.

Heterocycles switch an agonist to an antagonist conformation. To understand the molecular basis for these functional changes, we investigated the solution structures of these six compounds using 2D ROESY NMR spectroscopy. Two separate ROESY experiments are compared here for the three non-methylated heterocyclic ligands 1, 4 and $\mathbf{6}$ (Fig 1d) vs. the three methylated heterocyclic ligands 2, 3 and 5 (Fig. 1e). The three compounds in each of these experiments were dissolved together in the same NMR tube at a concentration of $3 \mathrm{mM}$ to ensure that agonists and antagonists were compared under the same conditions and that relative ROE intensities were consistent. The antagonist compounds 4, 5 and 6 all showed a strong ROE correlation for the amide- $\mathrm{NH} . . . \mathrm{H}$ or $\mathrm{CH}_{3}$ of heterocycle, indicating close proximity and a S-C-C-O dihedral angle of $\sim 0^{\circ}$. Through-space distances of 2.1-3.5 $\AA$ (for different methyl group rotamers) were measured from molecular models. Conversely, agonists 1, 2 and 3 showed no amide- $\mathrm{NH}$....H or $\mathrm{CH}_{3}$-heterocycle cross-peaks (expected in the boxed regions, Fig. 1e, f) consistent with larger through-space distances. Molecular modeling suggests distances between 4.7 and $5.8 \AA$, consistent with a N-C-C-O dihedral angle of $\sim 180^{\circ}$. This is the first direct experimental evidence revealing that heterocycles in $\mathrm{C} 3 \mathrm{a}$ ligands dictate structure by adopting one of two discrete conformations in solution, with the $\mathrm{X}-\mathrm{C}-\mathrm{C}-\mathrm{O}$ dihedral angle being $0^{\circ}$ or $180^{\circ}$ in agreement with theoretical models ${ }^{20}$. A consequence of this heterocycle-induced conformational switch is that the arginine is positioned differently in agonists vs. antagonists (Fig. 1f, blue surface). We attribute this conformational switching to an attractive S...O interaction between the thiazole/thiophene sulfur and the amide carbonyl oxygen in 4-6, fixing the carbonyl oxygen in such a conformation that evidently facilitates antagonist activity. This kind of attractive S...O interaction has been shown in crystal structures of other thiazoles and thiophenes ${ }^{20}, 22$. On the other hand, in $\mathbf{1 - 3}$ there is no attractive heterocycle-N...O-amide carbonyl interaction, instead the opposite amide orientation is preferred and this conformation clearly favors agonist activity. These highly original findings demonstrate that key functional activities (Fig. 1b, c) of 
a<smiles>[R]c1sc(C(c2ccccc2)c2ccccc2)nc1C(=O)N[C@@H](CCCNC(=N)N)C(=O)O</smiles><smiles>Cc1[nH]c(C(c2ccccc2)c2ccccc2)nc1C(=O)N[C@@H](CCCNC(=N)N)C(=O)O</smiles>

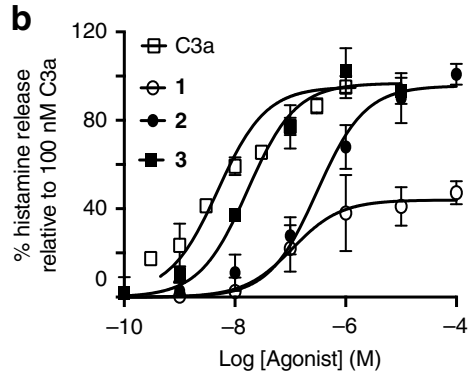

d

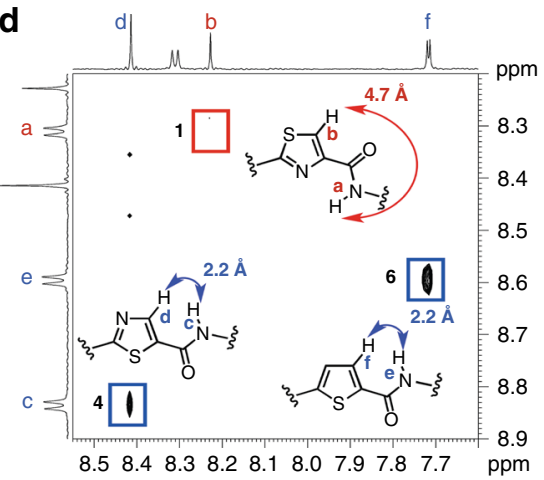

f

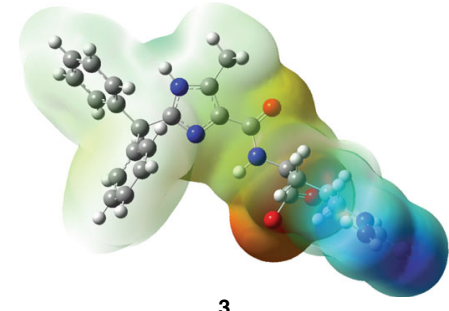<smiles>[R]c1nc(C(c2ccccc2)c2ccccc2)sc1C(=O)NC(CCCNC(=N)N)C(=O)O</smiles><smiles>N=C(N)NCCCC(NC(=O)c1ccc(C(c2ccccc2)c2ccccc2)s1)C(=O)O</smiles>
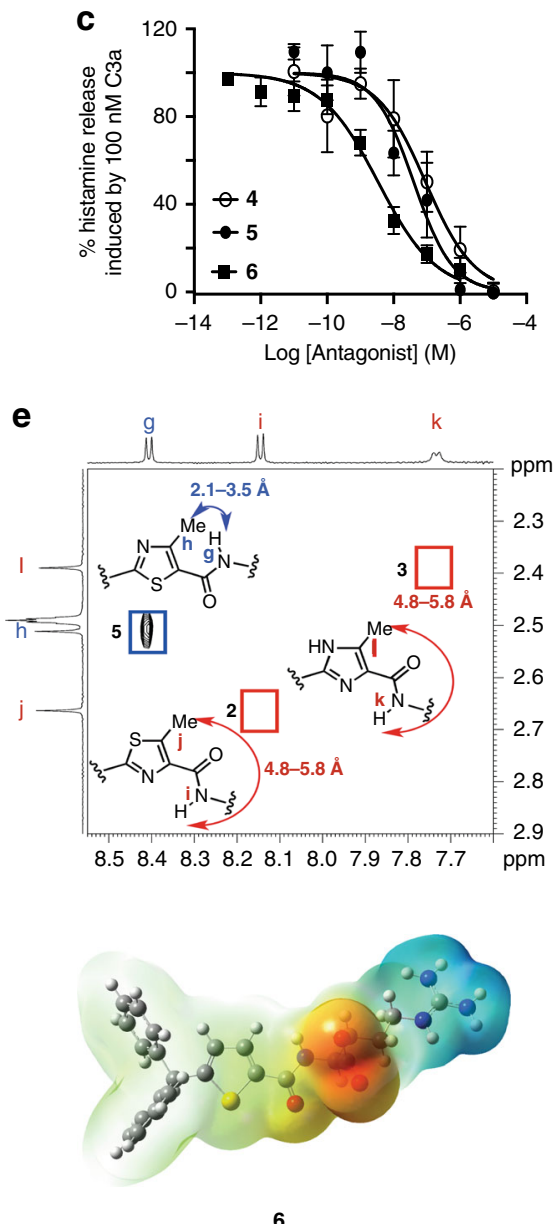

Fig. 1 Structures and activities for human C3aR agonists and antagonists. a Chemical structures of synthetic compounds 1-6; b, c Concentration-dependent histamine secretion in human LAD2 mast cells induced by: $\mathbf{b} \mathrm{hC} 3 \mathrm{a}\left(\mathrm{EC}_{50} 3 \pm 1.5 \mathrm{nM}\right)$ vs. agonists $\mathbf{1}\left(\mathrm{EC}_{50} 110 \pm 40 \mathrm{nM}\right), \mathbf{2}\left(\mathrm{EC}_{50} 300 \pm 100 \mathrm{nM}\right)$ or $\mathbf{3}$ (EC 50 $20 \pm 10 \mathrm{nM})$ alone. $\mathbf{c ~ h C 3 a}(100 \mathrm{nM})$ was inhibited by antagonist $\mathbf{4}\left(\mathrm{IC}_{50} 90 \pm 50 \mathrm{nM}\right)$ or $\mathbf{5}\left(\mathrm{IC}_{50} 40 \pm 20 \mathrm{nM}\right)$ or $\mathbf{6}\left(\mathrm{IC} \mathrm{C}_{50} 3.5 \pm 1.5 \mathrm{nM}\right)$. All the data $n \geq 3$, error bars are $\pm \mathrm{SEM}$; d, e 2D ROESY ${ }^{1} \mathrm{H}-\mathrm{NMR}$ spectra in DMSO- $\mathrm{d}_{6}$ for 1-6. $\mathbf{d}$ Amide NH...aromatic CH ROE correlations (c,d and e,f labeled protons, blue boxes) for antagonists $\mathbf{4}$ and $\mathbf{6}$, but not for agonist $\mathbf{1}$ (a,b labeled protons expected in red box). e 2D ROESY ${ }^{1} \mathrm{H}-\mathrm{NMR}$ spectra in DMSO-d 6 show amide $\mathrm{NH} . . . \mathrm{Me}$ ROE correlations for antagonist $\mathbf{5}$ (h, g labeled protons, blue box) but not for agonists $\mathbf{2}$ and $\mathbf{3}$ (i,j or k,l labeled protons expected in red boxes). The data indicate a distinct conformational difference between agonists $(\mathbf{1}, \mathbf{2}, \mathbf{3})$ and antagonists $(\mathbf{4}, \mathbf{5}, \mathbf{6})$. $\mathbf{f}$ Energy minimized structures with electrostatic surface potential maps for agonist $\mathbf{3}$ and antagonist $\mathbf{6}$ show the respective X-C-C-O dihedral angles and dramatically different orientations of the Arg residue. Ab initio calculations (DFT B3LYP/6-311g(2d,2p)) were performed using Gaussian 09 and imaged with GaussView 5 

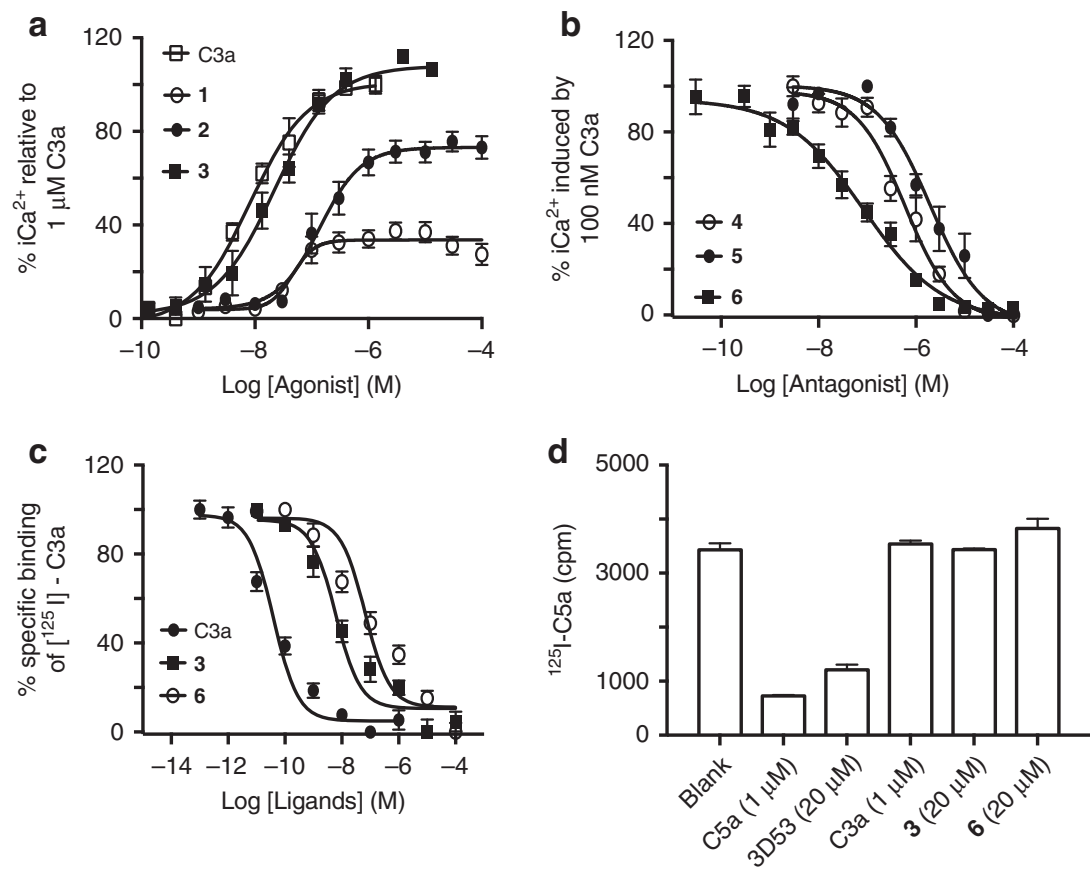

Fig. 2 Binding and functional selectivity of C3aR ligands on human macrophages. $\mathbf{a}$, b Concentration-dependent $\mathrm{Ca}^{2+}$ release in human monocyte-derived macrophages (HMDMs) induced by: a hC3a $\left(E_{50} 8 \pm 2 \mathrm{nM}\right)$ and agonists $\mathbf{1}\left(\mathrm{EC}_{50} 50 \pm 20 \mathrm{nM}\right), \mathbf{2}\left(\mathrm{EC}_{50} 140 \pm 60 \mathrm{nM}\right)$ or $\mathbf{3}$ (EC $\left.5022 \pm 8 \mathrm{nM}\right)$. b hC3a $(100 \mathrm{nM})$ induced $\mathrm{Ca}^{2+}$ release is inhibited by antagonist $4\left(\mathrm{IC}_{50} 600 \pm 200 \mathrm{nM}\right)$ or $\mathbf{5}\left(\mathrm{IC}_{50} 2 \pm 1.1 \mu \mathrm{M}\right)$ or $\mathbf{6}\left(\mathrm{IC} \mathrm{C}_{50} 85 \pm 40 \mathrm{nM}\right)$; c C3aR-binding affinities of hC3a, agonist 3 and antagonist 6 measured by competition with $\left[{ }^{125} \mathrm{I}\right]$-hC3a (80 pM) on HMDMs. d C5aR-binding of hC5a and C5aR selective antagonist (3D53), but no binding of hC3a, agonist $\mathbf{3}$ or antagonist $\mathbf{6}$ as measured by competition with [ $\left.{ }^{125} \mathrm{I}\right]-\mathrm{hC} 5 \mathrm{a}(25 \mathrm{pM})$ on HMDMs. All the data $n \geq 3$, error bars are \pm SEM

heterocyclic ligands acting at the human $\mathrm{C} 3 \mathrm{a}$ receptor can be switched by changing the heteroatom and, consequently, the ligand conformation (Fig. 1d-f).

Heterocycles switch ligand function on human macrophages. The same functional trends observed for compounds 1-6 on histamine secretion in human mast cells (Fig. 1b, c) were also observed for intracellular $\mathrm{Ca}^{2+}$ release in human monocytederived macrophages, with 1-3 being agonists (Fig. 2a) and 4-6 being antagonists of $\mathrm{C} 3 \mathrm{a}$-induced intracellular $\mathrm{Ca}^{2+}$ release (Fig. 2b). The most potent agonist 3 and antagonist $\mathbf{6}$ were found to compete with ${ }^{125}$ I-labelled C3a (Fig. 2c), but not with ${ }^{125}$ I-labelled C5a (Fig. 2d), for binding to human macrophages, indicating binding and selectivity for C3aR over C5aR. Their reduced affinity relative to human $\mathrm{C} 3 \mathrm{a}$ is most likely due to the absence of the high affinity binding $\mathrm{N}$-terminal helix bundle domain of $\mathrm{C} 3 \mathrm{a}$, but this did not affect the functional potency of the small molecules (Fig. 2a, b). This is most likely due to the small molecules binding only at the effector site on C3aR, like the low affinity effector $\mathrm{C}$-terminal tetrapeptide sequence of $\mathrm{C} 3 \mathrm{a}$.

We also checked possible binding of C3a-desArg to C3aR on Human Embryonic Kidney HEK293 cells transfected with human $\mathrm{C} 3 \mathrm{aR}\left(\mathrm{C} \mathrm{aR}^{++}\right)$and found no binding (Fig. 3a), indicating that only intact $\mathrm{C} 3 \mathrm{a}$ can activate $\mathrm{C} 3 \mathrm{aR}$ and that the known removal of the C-terminal arginine of $\mathrm{C} 3 \mathrm{a}$ by carboxypeptidases in plasma abrogates C3a activity. Next, we demonstrated the specificity and on-target action of $\mathbf{3}$ and $\mathbf{6}$ further in different cell types. Their selectivity for the $\mathrm{C} 3 \mathrm{a}$ receptor was indicated by lack of function on wild-type HEK293 cells $\left(\mathrm{C}_{3} \mathrm{aR}^{-/-}\right)$, which do not express the C3a receptor ${ }^{23}$ (Fig. 3b) but do endogenously express many other human GPCRs and proteins ${ }^{24,25}$. C3a, 3 and $\mathbf{6}$ did not induce $\mathrm{Ca}^{2+}$ release, unlike calcimycin, in these $\mathrm{C}^{2} \mathrm{aR}^{-1-}$ cells (Fig. $3 \mathrm{~b}$ ).

In contrast, both $\mathrm{C} 3 \mathrm{a}$ and 3 did induce $\mathrm{Ca}^{2+}$ release in human

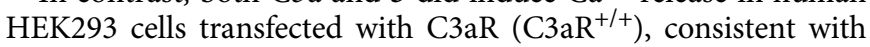

their specificity and on-target action on $\mathrm{C} 3 \mathrm{aR}$ (Fig. 3c). This induction in intracellular $\mathrm{Ca}^{2+}$ release was prevented by pretreatment with 6 for 30 min before the addition of either C3a or 3 to C3aR-HEK293 cells (Fig. 3c). Further, the C3a antagonist 6 dose-dependently antagonized intracellular $\mathrm{Ca}^{2+}$ release induced by agonist 3 in human macrophages (Fig. 3d). There was a rightward shift in the observed potency of agonist 3 competing with increasing concentrations of $\mathbf{6}$ in macrophages, with a Schild plot slope of $0.77 \pm 0.05\left(r^{2}=0.99\right)$ (Fig. 3d). The decreasing amplitude of the agonist response with increasing antagonist is consistent with insurmountable antagonism, hinting that $\mathbf{6}$ may have a longer residence time than 3 on the receptor.

Plasma and liver microsomal stability. In preparation for evaluating the most potent agonist (compound 3, designated BR103) and antagonist (compound 6, designated BR111) in vivo, the in vitro stability of these compounds were examined in rat plasma and in rat liver microsomes. These assays provide a measure of stability towards degradation by proteolytic and cytochrome $\mathrm{P} 450$ enzymes, respectively. Compounds 3 and $\mathbf{6}$ remained intact after exposure to plasma, whereas $\mathrm{C} 3 \mathrm{a}$ degraded within minutes in plasma (Fig. 3e), a property previously attributed to cleavage by circulating carboxypeptidases ${ }^{26}$. Furthermore, compounds 3 and 6 were much more stable than C3a in liver microsomes, known to be rich in cytochrome P450 enzymes, as reflected by their lower intrinsic clearance rates (Fig. 3f). These results suggested that compounds 3 and $\mathbf{6}$ could potentially be more stable and more bioavailable in vivo than $\mathrm{C} 3 \mathrm{a}$ or its peptide analogues, and thus represent important and novel small molecule leads for modulating C3aR biology in vivo.

Agonist induced acute rat paw edema and immune responses. C3a-induced inflammatory responses via activation of C3aR have been extensively studied in vitro in human and rodent immune 
a
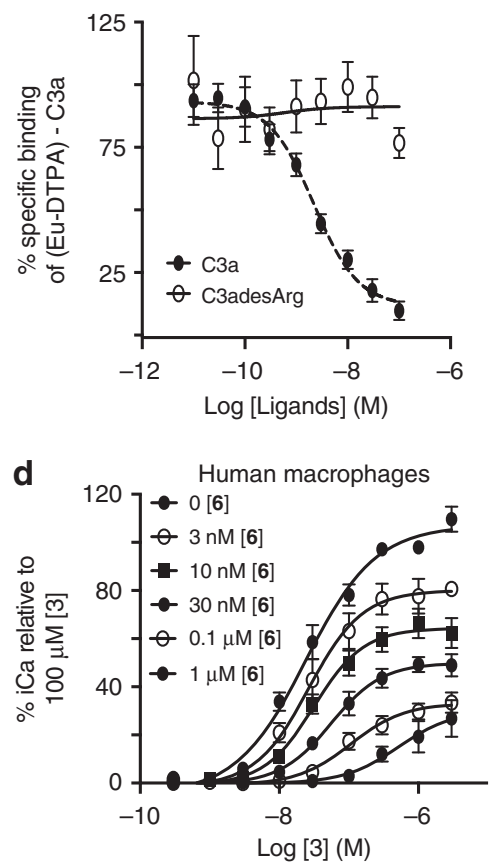

b

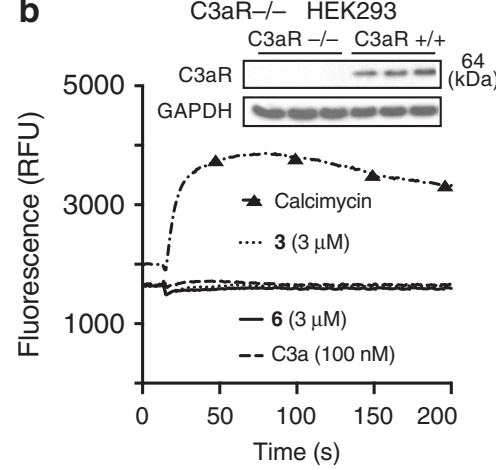

e

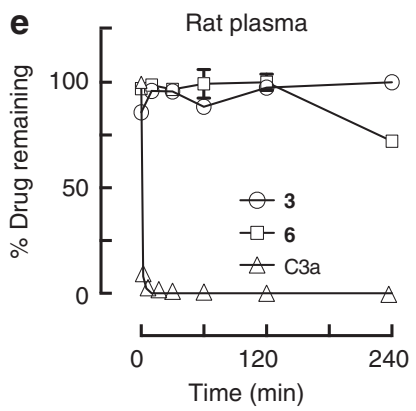

C

C3aR+/+ HEK293
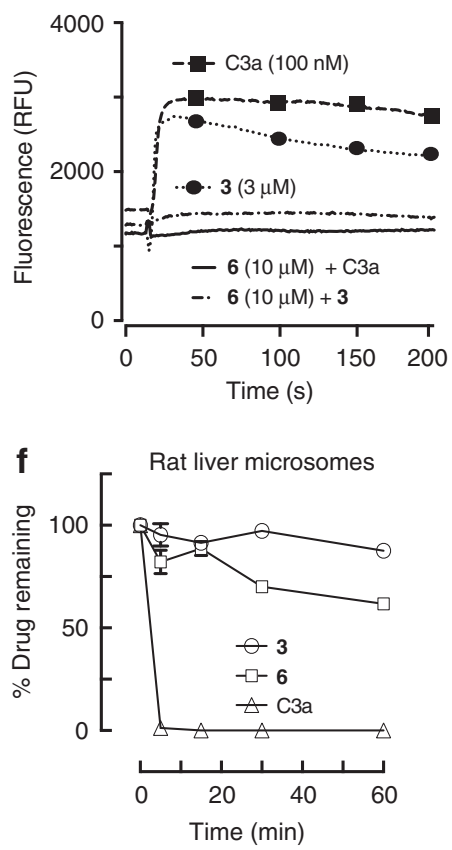

Fig. 3 Binding and function of C3aR ligands on HEK293 and HMDM cells. a C3aR-binding affinities of hC3a and hC3a-desArg measured by competition with [Eu DTPA]-hC3a ( $2 \mathrm{nM})$ on human HEK293 cells transfected with C3aR (C3aR $\left.{ }^{+/+}\right)$; b western blot showing no human C3aR expression, and fluorescence plots showing no intracellular $\mathrm{Ca}^{2+}$ release induced by C3a, 3 or $\mathbf{6}$ (vs. positive control: calcimycin) in wild-type human $\mathrm{HEK}^{293}$ cells (C3aR ${ }^{-/}$); c Intracellular $\mathrm{Ca}^{2+}$ release induced by C3a or $\mathbf{3}$ alone or in the presence of $\mathbf{6}$ (pre-treated 30 min before adding C3a or $\mathbf{3}$ ) in human HEK293 cells transfected with $\mathrm{C} 3 \mathrm{aR}\left(\mathrm{C}_{3} \mathrm{R}^{+/+}\right)$; d Concentration dependent iCa ${ }^{2+}$ release induced by agonist $\mathbf{3}$ in the presence of 0-1000 $\mathrm{nM}$ antagonist $\mathbf{6}$ (pre-treated 30 min before adding agonist), relative to $100 \%$ response for $100 \mu \mathrm{M} \mathbf{3}$ on HMDMs. All the data in a-d, $n \geq 3$, error bars \pm SEM. e, $\mathbf{f}$ Metabolic stability for agonist $\mathbf{3}$ and antagonist $\mathbf{6}$ vs hC3a in e rat plasma over $4 \mathrm{~h}$ and $\mathbf{f}$ rat liver microsomes over $1 \mathrm{~h}$, illustrating greater stability of $\mathbf{3}$ and $\mathbf{6}$ over hC3a

cells $^{4-6}$. However, teasing out the roles of C3a and C3aR in vivo and mechanisms of acute and chronic inflammatory diseases have proven to be more difficult. Studies using recombinant C3a in vivo in rodents are now thought to have been compromised by rapid degradation of $\mathrm{C} 3 \mathrm{a}$ due to carboxypeptidase action to form C3a des-Arg ${ }^{4-6}$. C3a des-Arg has a completely different pharmacological profile compared to $\mathrm{C} 3 \mathrm{a}$, and does not bind to $\mathrm{C} \mathrm{aR}^{4-6}$, as confirmed above (Fig. 3a). Thus, here we used our more metabolically stable and C3aR-selective small molecule agonist BR103 (compound 3) to characterize for the first time a $\mathrm{C} 3 \mathrm{aR}$-induced innate immune response in vivo in rats. An acute inflammatory response and edema can be induced in rodents by an intraplantar injection of substances such, as $\lambda$-carrageenan into, the rear paws leading to leukocytosis and a hyperemic response, which produces localized swelling 27 . Similarly, we aimed here to investigate if selective activation of $\mathrm{C} 3 \mathrm{aR}$ in vivo in rats would induce an acute inflammatory edema and to characterize the innate immune responses over a $24 \mathrm{~h}$ time course (Fig. 4).

A single intraplantar injection of the C3aR agonist, BR103 (compound 3), induced an acute inflammatory edema, similar to that shown by $\lambda$-carrageenan and other irritants, with localized paw swelling, mast cell activation, histamine and tryptase release, myeloperoxidase (MPO) activation, leukocyte recruitment and expression of various proinflammatory cytokines in a timedependent manner (Figs. $4 \mathrm{a}-\mathrm{h}$ and $5 \mathrm{a}-\mathrm{i}$ ). The BR103-induced paw swelling peaked at $0.5 \mathrm{~h}$ and returned to baseline after $24 \mathrm{~h}$ (Fig. 4a). Histological evaluation at the various time points after BR103 administration suggested that resident mast cell activation and degranulation (Fig. 4b, c) was associated with paw inflammation, which preceded the infiltration and activation of other leukocytes such as inflammatory macrophages and neutrophils. The BR103-induced peak paw swelling at $0.5 \mathrm{~h}$ was concurrent with an increased number of activated mast cells, together with increased histamine secretion and decreased tryptase-positive cells in paw tissue compared to vehicle-treated animals (Fig. 4d-f). This increase in mast cell activation and degranulation at $0.5 \mathrm{~h}$ was a temporal response, since activated mast cells subsided at $6 \mathrm{~h}$ and $24 \mathrm{~h}$ time points after C3aR activation (Fig. 4c).

Interestingly, BR103 also induced a temporal increase in infiltration of inflammatory $\mathrm{ED}^{+}$macrophages at $0.5 \mathrm{~h}$ (Fig. 5a, b) without significantly affecting resident ED $2^{+}$macrophage cell numbers in paws compared to vehicle-treated animals (Fig. 4g, h). Further, BR103 also increased infiltration and activation of other granulocytes and leukocytes such as neutrophils compared to vehicle-treated animals (Fig. $5 c, d$ ). However, activation of neutrophils (measured as increased activity of MPO) and accumulation of other granulocytes and leukocytes were not observed until $6 \mathrm{~h}$ after BR103 administration (Fig. 5c,d), suggesting a temporal involvement following recruitment to the site of inflammation.

Moreover, since both immune and non-immune cells have been implicated in C3aR-induced innate immune responses ${ }^{6}$, we further characterized changes in inflammatory gene expression in rat paw tissue at $0.5,6$ and $24 \mathrm{~h}$ after BR103 administration (Fig. 5e-i). BR103 induced the upregulation of many proinflammatory genes, such as Ill $\beta, I l 6, \operatorname{Tnf}, C c l 3$, and $M c p 1$, compared to vehicle-treated animals (Fig. 5e-i). Most of these $\mathrm{C} 3 \mathrm{aR}$-induced inflammatory markers are early response genes, peaking at $0.5 \mathrm{~h}$ and slowly subsiding over $6 \mathrm{~h}$ and $24 \mathrm{~h}$ time points after BR103 administration (Fig. 5e-i). 

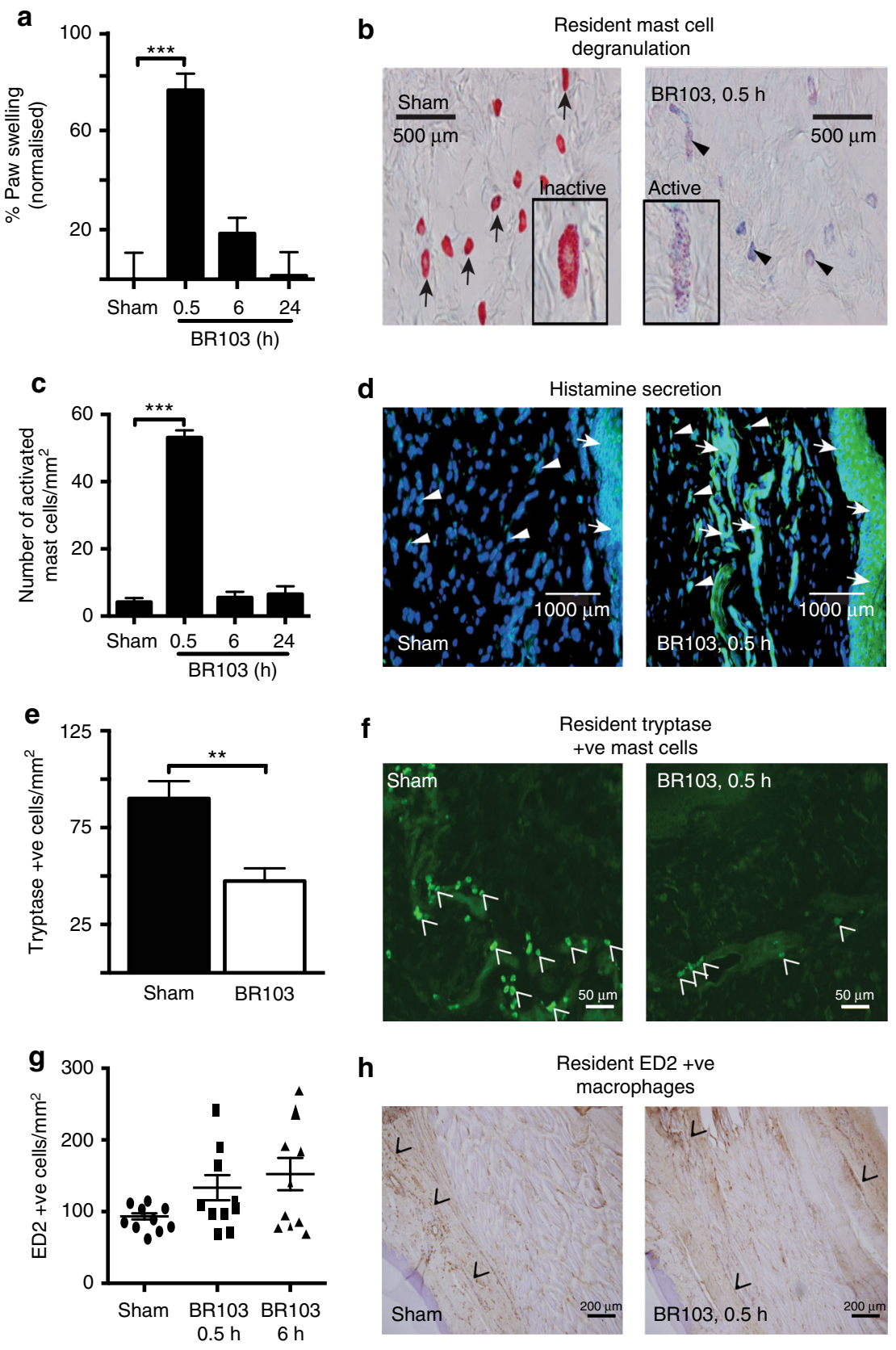

Fig. 4 Agonist 3 (BR103) induces paw oedema and mast cell activation in rats. BR103 (350 $\mu$ g per paw, i.pl.) induces: a paw swelling, which peaked at $30 \mathrm{~min}$ and returned to near basal levels at $24 \mathrm{~h} ; \mathbf{b}$ activation/degranulation mast cells at 30 min stained purplish blue by alcian blue (arrowheads), whereas inactive mast cells stained red with safranin O (arrows), Scale bar: $500 \mu \mathrm{m}$; c Quantification of increased activated mast cells at 30 min, not present at $6 \mathrm{~h}$ or $24 \mathrm{~h}$, compared to sham (vehicle) based on staining with alcian blue and safranin O; d histamine release at 30 min compared to sham (vehicle), as demonstrated by immunohistochemistry staining of histamine, the blue dye stains for the cell nucleus (white arrowheads), while the green dye stains for histamine (white arrows - diffused extracellular histamine staining), Scale bar: $1000 \mu \mathrm{m} ; \mathbf{e}, \mathbf{f}$ tryptase-+ve mast cells are decreased at 30 min compared to sham (vehicle) $\mathbf{e}$, as demonstrated in the immunohistochemistry staining of mast cell tryptase $\mathbf{f}$, the green dye stains for intact cellular mast cell tryptase in non-degranulated mast cells (white chevron - tryptase + ve cells), Scale bar: $50 \mu \mathrm{m} ; \mathbf{g}, \mathbf{h}$ Quantification $\mathbf{g}$ and representative images $\mathbf{h}$ of resident $\mathrm{ED}^{+}$macrophages (black chevron) at $30 \mathrm{~min}$ and $6 \mathrm{~h}$ compared to sham (vehicle) as demonstrated by immunohistochemistry staining, Scale bar: $200 \mu \mathrm{m}$. Error bars represent mean \pm SEM. ${ }^{\star} P<0.05 ;{ }^{\star \star} P<0.01 ;{ }^{\star \star \star} P<0.005$ (one-way ANOVA, Uncorrected Fisher's LSD post hoc comparison, a, $\mathrm{C}, \mathrm{g}$ ), student's t-test e.). 8- to 9-week-old male Wistar rats $(n=29)$ were used for this experiment

Antagonism of acute edema and innate immune responses. Dysregulated C3aR expression and activation have been shown to be involved in various chronic inflammatory disease conditions ${ }^{4-6}$. Verifying that our novel small molecule C3aR antagonists have in vivo functionality would furnish useful therapeutic tools for regulating acute and chronic inflammatory disease conditions. BR111 (compound 6) was assessed in vivo in the above rat model of acute inflammatory edema induced by C3aR agonist, BR103. When given as an oral pretreatment, BR111 strongly inhibited acute rat paw edema, induced $2 \mathrm{~h}$ later by i.pl. injection of BR103 (Fig. 6a). Orally administered BR111 inhibited BR103induced paw swelling at $30 \mathrm{~min}$ in a dose-dependent manner, suggesting specificity and competition for $\mathrm{C} 3 \mathrm{aR}$ in vivo (Fig. 6a). Furthermore, this pre-treatment with BR111 attenuated 


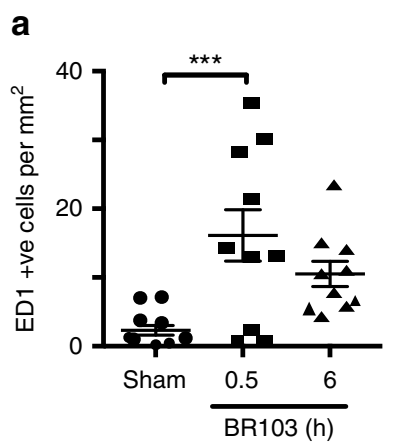

b

Infiltrated ED1 +ve
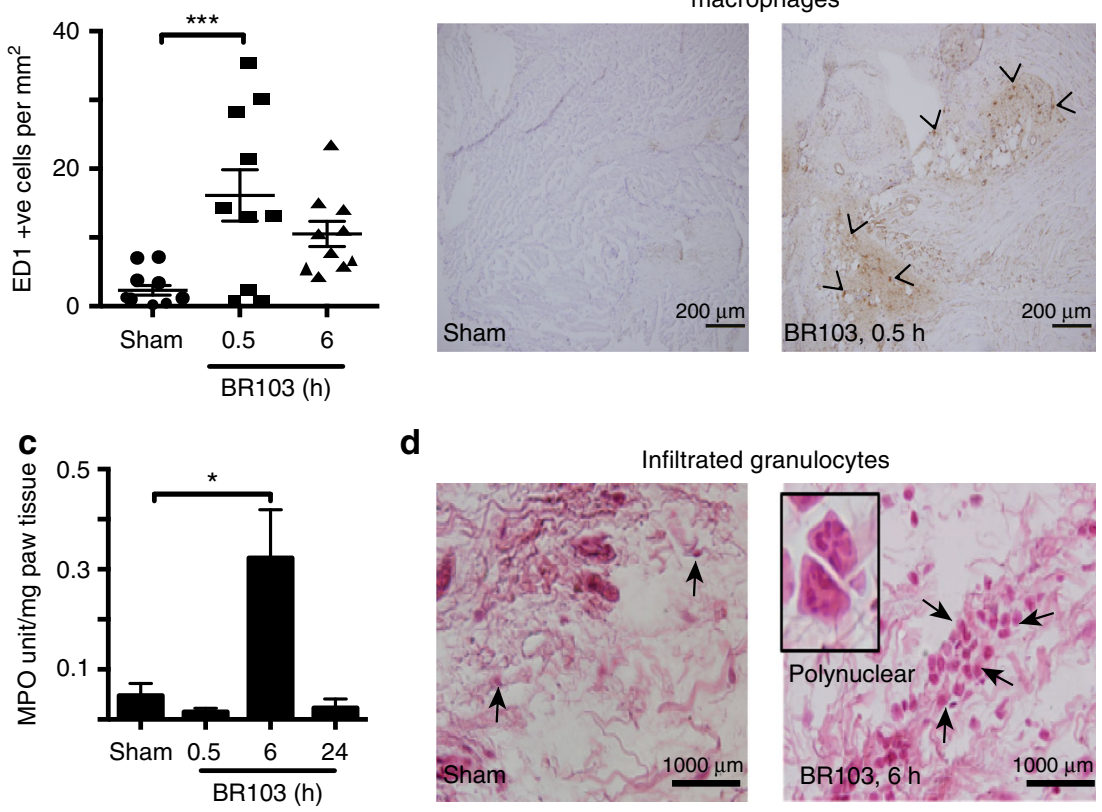

d
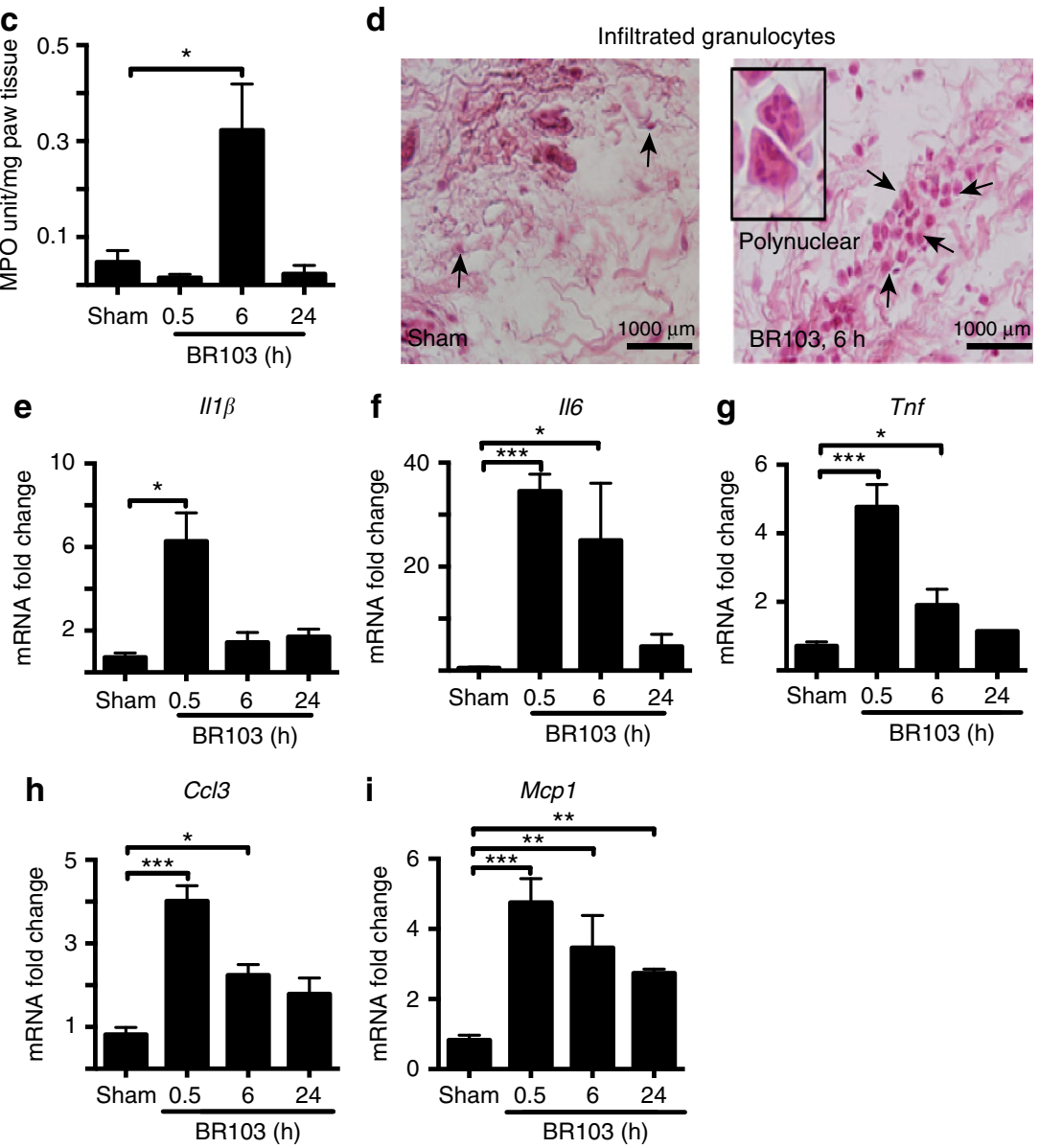

Fig. 5 Agonist 3 (BR103) induces temporal inflammatory responses in rat paws. BR103 (compound 3, $350 \mu \mathrm{gg} /$ paw, i.pl.) induces: a, b increased infiltration of $E D 1^{+}$macrophages at 30 min but much less at $6 \mathrm{~h}$ compared to sham (vehicle) as demonstrated by immunohistochemistry staining of ED $1^{+}$(black chevron), Scale bar: $200 \mu \mathrm{m}$; c increased myeloperoxidase (MPO) activity at $6 \mathrm{~h}$, but not at $30 \mathrm{~min}$ or $24 \mathrm{~h}$ compared to sham (vehicle); $\mathbf{d}$ infiltrated leukocytes and granulocytes after $6 \mathrm{~h}$ compared to sham (vehicle) (arrowheads - granulocytes), Scale bar: $1000 \mu \mathrm{m}$; e-i upregulation of proinflammatory genes such as $1 / 1 \beta \mathbf{e}, 116 \mathbf{f}, \operatorname{Tnf} \mathbf{g}, \mathrm{Cc} / 3 \mathbf{h}$, and Mcp1 i, which peaked at $30 \mathrm{~min}$ compared to sham (vehicle). Error bars represent mean $\pm \mathrm{SEM}$.

${ }^{\star} P<0.05 ;{ }^{\star \star} P<0.01 ;{ }^{\star \star \star} P<0.005$ (one-way ANOVA, Uncorrected Fisher's LSD post hoc comparison). 8- to 9-week-old male Wistar rats ( $\left.n=29\right)$ were used for this experiment

BR103-induced acute inflammatory responses such as mast cell activation and degranulation (Fig. 6c, d) and secretion of histamine (Fig. 6e), in these rat paws at $0.5 \mathrm{~h}$ after agonist administration. BR111 also attenuated neutrophil activation at $6 \mathrm{~h}$ after BR103 administration (Fig. 6b). BR111 also prevented the increased infiltration of inflammatory ED1 macrophages at $0.5 \mathrm{~h}$ in paws compared to BR103-treated animals (Fig. 6f, g). These effects were observed together with the suppression of BR103-induced gene expression of proinflammatory cytokines and chemokines by oral BR111 treatment (Fig. 6h-l).
These results strongly suggest that the novel C3aR ligand, BR111 (compound 6), is a potent, selective, orally active antagonist of $\mathrm{C} 3 \mathrm{aR}$ with beneficial anti-inflammatory properties in vivo. In summary, the data are consistent with C3aR being activated in vivo by BR103 (compound 3) and antagonized by BR111 and have helped to characterize for the first time the direct responses of selective $\mathrm{C} 3 \mathrm{aR}$ activation and inhibition in vivo on acute innate immune responses.

Mast cell stabilizer attenuates C3aR inflammation in rats. Finally, we investigated whether the C3aR agonist-induced acute 
a

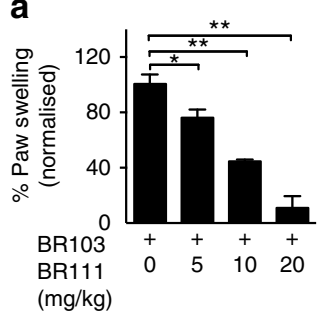

b

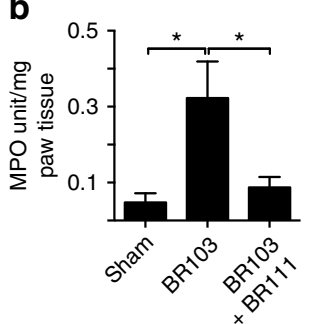

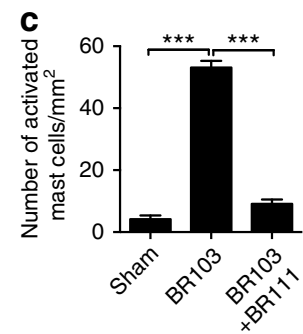

d

Resident mast cell degranulation
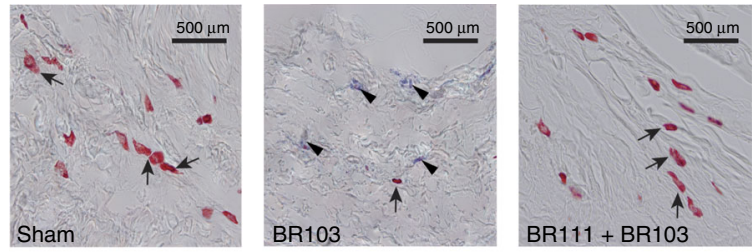

e

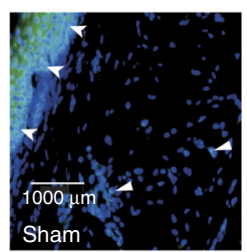

Histamine secretion
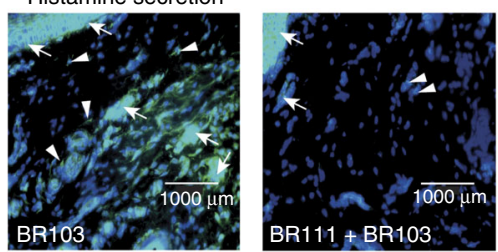

f

Infiltrated ED1 +ve macrophages
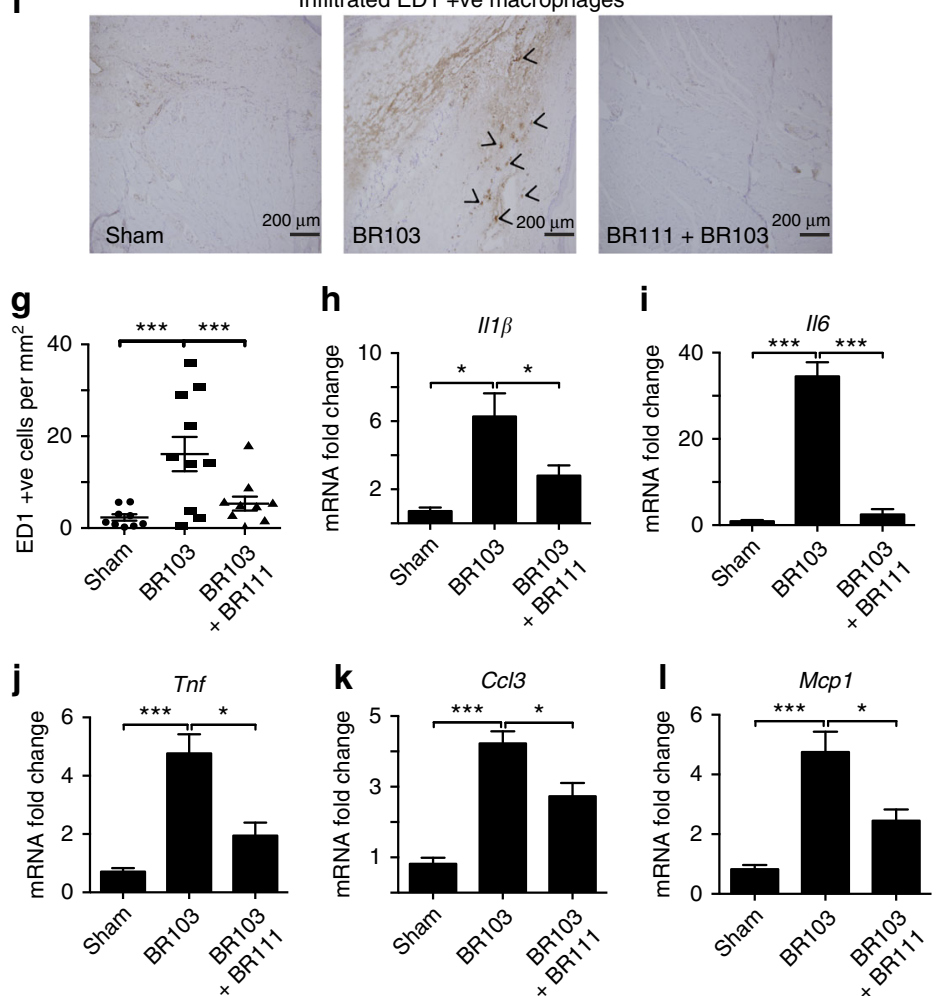

Fig. 6 Antagonist BR111 (6) inhibits inflammatory responses induced by BR103 (3) in rats. Oral pre-treatment with BR111 (6, 20 mg/kg p.o., $2 \mathrm{~h}$ prior) inhibits BR103 (3,350 $\mathrm{g} / \mathrm{paw}$, i.pl.) induced: a paw swelling at $30 \mathrm{~min}$ in a dose-dependent manner; $\mathbf{b}$ increased MPO activity at $6 \mathrm{~h}$; $\mathbf{c}$, $\mathbf{d}$ activated/ degranulated mast cells at 30 min stained purplish blue by alcian blue (arrowheads), whereas inactive mast cells stained red with safranin $\mathrm{O}$ (arrows), Scale bar: $500 \mu \mathrm{m}$; e histamine secretion in rat paw tissue at $30 \mathrm{~min}$, as demonstrated by immunohistochemistry staining of histamine, the blue dye stains for the cell nucleus (white arrowheads), while the green dye stains for histamine (white arrows - diffused extracellular histamine staining), Scale bar: $1000 \mu$ m; $\mathbf{f}, \mathbf{g}$ increased infiltration of ED1 ${ }^{+}$macrophages (black chevron) at 30 min as demonstrated by immunohistochemistry staining, Scale bar: $200 \mu$ m; $\mathbf{h}-\mathbf{I}$ expression of inflammatory genes at $30 \mathrm{~min} I 11 \beta \mathbf{h}, 116 \mathbf{i}, \operatorname{Tnf} \mathbf{j}, C \mathrm{Cl} 3 \mathbf{k}$, and Mcp1 I. Error bars represent mean $\pm \mathrm{SEM}$. ${ }^{\star} P<0.05$; ${ }^{\star \star} P<0.01$; ${ }^{\star \star \star} P<0.005$ (one-way ANOVA, Uncorrected Fisher's LSD post hoc comparison) 8-to 9-week-old male Wistar rats $(n=27)$ were used for this experiment 
inflammatory edema and immune response in vivo was specifically mediated by a mast cell-dependent mechanism or whether resident or infiltrating macrophages or neutrophils were contributors. Resident mast cells are generally localized at peripheral sites, including the skin, airways, gut, and other tissues. Rapid activation of mast cells has been shown to initiate inflammation through the release of both pre-formed and synthesized mediators, which induce increased vasopermeability, vasodilation, accumulation of inflammatory mediators, and chemotaxis of other immune cells ${ }^{28-30}$. Thus, to further characterize mechanistically if BR103-induced acute inflammatory edema in rats was mostly mediated via mast cells, we investigated the pharmacological responses of a known mast cell stabilizer, cromolyn, on inflammation induced by BR103 (compound 3). Cromolyn is believed to prevent mast cell degranulation by stabilizing the cell membrane and it is currently used to treat various mast cell related diseases such as asthma, conjunctivitis, allergic rhinitis, and mastocytosis ${ }^{31}$. When rats were pretreated with cromolyn $(20 \mathrm{mg} / \mathrm{kg}$ s.c., $30 \mathrm{~min}$ prior $)$ there was a significant reduction in BR103-induced paw swelling at $0.5 \mathrm{~h}$, almost back to baseline levels (Fig. 7a). Cromolyn treatment in vivo also attenuated BR103-induced increased activation (Fig. 7b) and degranulation (Fig. 7c) of mast cells together with reduced histamine expression (Fig. $7 \mathrm{~d}$ ) at $0.5 \mathrm{~h}$ in rat paws. This was followed by a reduced infiltration of inflammatory $\mathrm{ED}^{+}$macrophages at $0.5 \mathrm{~h}$ in rat paws compared to BR103-treated animals (Fig. 7e, f) and a reduced expression of early response inflammatory genes, including $I l 1 \beta, I l 6, T n f, C c l 3$, and $M c p 1$ at $0.5 \mathrm{~h}$ (Fig. $7 \mathrm{~g}-\mathrm{k}$ ). Taken together, these findings indicate that the direct activation of $\mathrm{C} 3 \mathrm{aR}$ in vivo by BR103 (compound 3) results in acute inflammatory edema and innate immune responses that are specifically initiated via a mast cell-dependent mechanism. Thus, $\mathrm{C} 3 \mathrm{aR}$ on resident mast cells clearly has a key initiating and amplifying role in acute events such as degranulation, histamine and tryptase secretion, leading to paw inflammation, cytokine expression and other associated innate immune responses in vivo. Other key innate immune cells such as infiltrating macrophages and neutrophils are subsequently recruited to the site of inflammation and can drive a sustained immune response, but they do not seem to be major contributors to the early acute innate immune response induced in vivo in rats through $\mathrm{C} 3 \mathrm{aR}$ activation.

\section{Discussion}

Human C3a (hC3a) is one of $\sim 30$ complement proteins produced in blood or on cell surfaces through activation by infection or injury $^{4-6}$. Collectively, they "complement" immune cells and antibodies to identify, tag, destroy, and eliminate pathogens and infected or damaged cells, and repair wounds ${ }^{4-6}$. If the inflammatory stimulus is not removed, complement activation becomes prolonged, or misdirected to healthy cells, causing or exacerbating chronic inflammatory or auto-immune diseases. Multiple pathways of complement activation produce $\mathrm{C} 3 \mathrm{a}$, which is thought to stimulate important immune and metabolic responses. Its human receptor, hC3aR is considered to be a key mediator of inflammatory disease $\mathrm{s}^{4-6}$, but current small molecule ligands for hC3aR are not sufficiently drug-like to be effective probes for in vivo studies. Development of potent, selective, metabolically stable and bioavailable ligands for $\mathrm{C} 3 \mathrm{aR}$ could be valuable new leads to a new class of therapies for treating complement-mediated diseases.

Here we describe different heterocycles adjacent to a carboxamide that can be used to control ligand conformation, as established by 2D NMR spectroscopic techniques. We have demonstrated how this conformational change, triggered by a simple change of heteroatom, profoundly impacts on ligand function, resulting in potent agonists (e.g., 3, BR103) or antagonists (e.g., 6, BR111). This chemical discovery has been then exploited to unravel new cell and in vivo biology, by examining the effects of potent and selective small molecule agonists that mimic $\mathrm{C} 3 \mathrm{a}$ in activating mast cells, macrophages and neutrophils, and of potent small molecule antagonists that block the actions of both C3a and BR103 on these innate immune cells. These small molecule modulators were selective for C3aR, showing functional responses on human LAD2 mast cells, HMDM cells, and HEK293 cells that expressed C3aR but not on $\mathrm{C}_{3} \mathrm{aR}^{-1-}$ HEK293 cells. They were also selective for C3aR over $\mathrm{C} 5 \mathrm{aR}$, and were metabolically stable chemical tools for use in animal models.

Direct administration of a potent $\mathrm{C} 3 \mathrm{aR}$ agonist intraplantar to rat paws elicited an acute edema and innate immune response, characterized by mast cell activation and degranulation, histamine and tryptase release, expression of inflammatory cytokines (IL-1 $\beta$, CCL3, IL6, TNF, MCP1), and macrophage and neutrophil infiltration. All of these measures of acute inflammatory responses were inhibited by oral pretreatment of a potent C3aR antagonist delivered systemically to rats. An important mechanistic finding was that the mast cell stabilizer cromolyn, which blocks degranulation of mast cells but does not inhibit neutrophil or macrophage functions, was also able to inhibit agonist-induced paw inflammation in rats. C3a and its small molecule agonist mimics are able to activate a range of innate immune cells such as mast cells, macrophages and neutrophils. However, these results support the conclusion that it is the mast cell that initiates the acute innate immune response and that other immune cells that infiltrate damaged or infected tissues subsequently drive inflammation.

Mast cells have been almost the forgotten innate immune cells until recently. They were identified over 100 years ago, are conserved across many species, yet their roles in immunity, defence and disease are still not completely defined ${ }^{30-32}$. They are special in containing as many as 500,000 secretory granules ${ }^{32}$, filled with numerous pre-formed and pre-activated immunomodulators ${ }^{30-32}$ that are released upon degranulation, but are also known to secrete inflammatory mediators in the absence of degranulation ${ }^{30,32}$. Although mast cells have been regarded as sentinels for infection and drivers of allergic and anaphylactic responses through $\operatorname{IgE}^{28}$, 33 , they are also emerging as potentially important contributors to chronic inflammatory diseases such as inflammatory bowel disease, irritable bowel syndrome, multiple sclerosis, arthritis, wound healing, graft rejection, angiogenesis, cancers, cardiovascular diseases, diabetes, obesity, and others ${ }^{28}$. Recent single-cell transcriptomic studies have identified new progenitor populations with mast-cell potential that are distinct from the neutrophilmonocyte lineage and that segregate early in hematopoietic development ${ }^{34}$. Transcriptomic analysis in isolated constitutive connective-tissue mast cells from skin, tongue, oesophagus, trachea, and the peritoneal cavity have identified distinct gene clusters for mast cells independent of other lymphoid and myeloid-cell populations ${ }^{30,35}$. These studies are revealing previously unappreciated mast-cell turnover rates and pre-activated secretory granule turnover in the periphery in the absence of tissue inflammation ${ }^{30,35}$. Human $\mathrm{C} 3 \mathrm{a}$ is known to degranulate mast cells in vitro to release histamine and tryptase ${ }^{21}$, but evidence for the action of C3a in vivo on mast cells remains clouded. Our data for $\mathrm{C} 3 \mathrm{aR}$ activation in rat paws by an agonist and blockade by an antagonist suggests that $\mathrm{C} 3 \mathrm{a}$ is proinflammatory in vivo through its action on resident mast cells in the skin, and that mast cell degranulation is a key initiator of acute inflammation in the paw and a stimulator of recruitment of other immune cells (macrophages, neutrophils) that are subsequently activated. Further studies using our novel ligands may help identify specific roles of mast cells in other distinct anatomical 

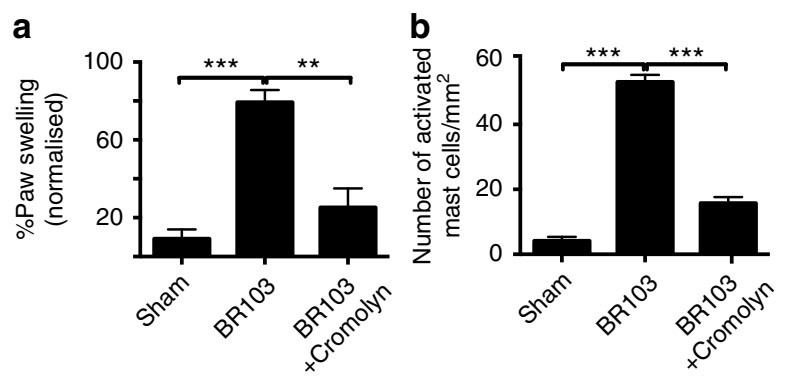

C

Resident mast cell degranulation
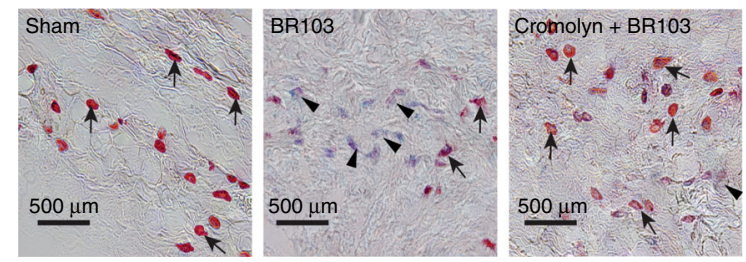

d

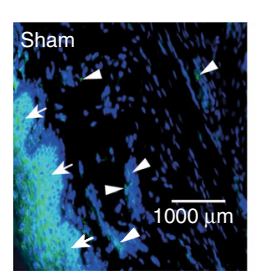

Histamine secretion

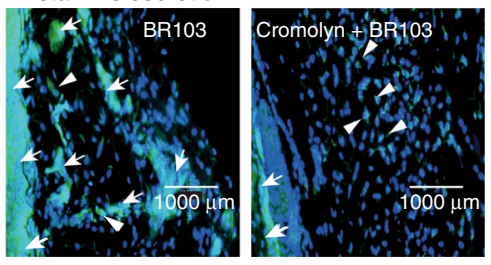

e

Infiltrated ED1 +ve macrophages
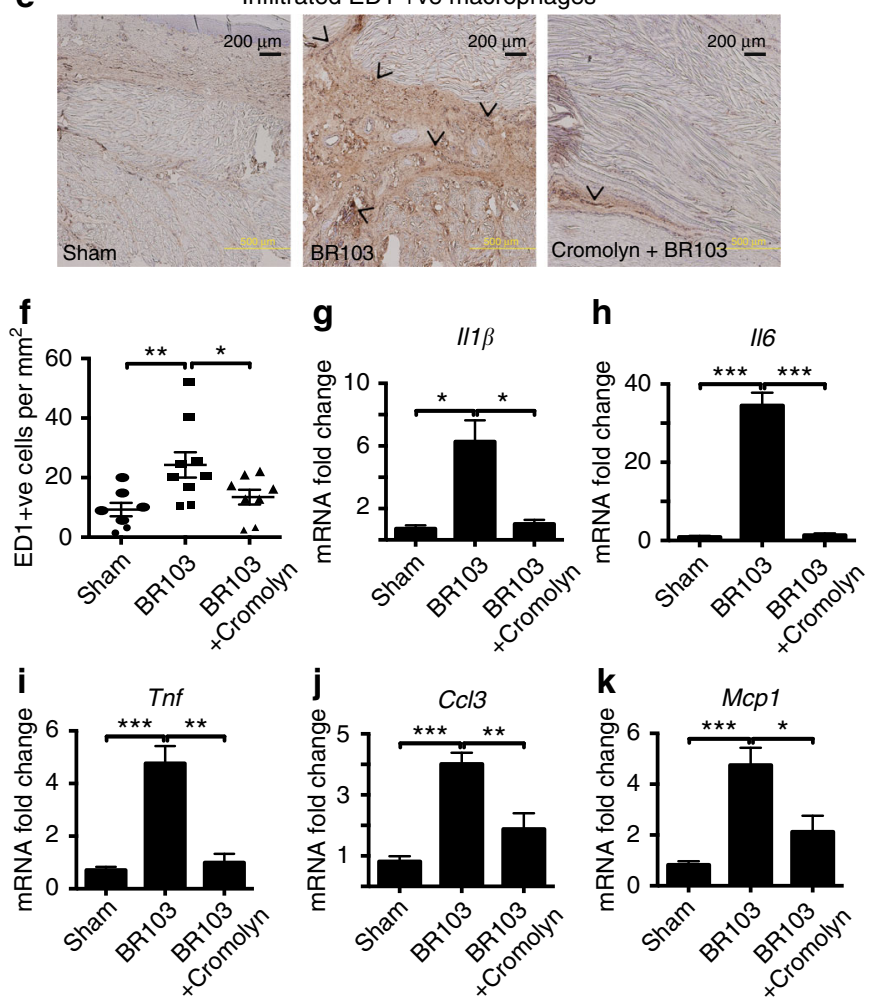

Fig. 7 Cromolyn inhibits BR103-induced inflammatory responses in rat paws. Pre-treatment with cromolyn (20 mg/kg s.c., 30 min) inhibits BR103 (compound 3, $350 \mu \mathrm{g} / \mathrm{paw}$, i.pl.) induced: a paw swelling at $30 \mathrm{~min}$; b, c activated/degranulated mast cells at 30 min stained purplish blue by alcian blue (arrowheads), whereas inactive mast cells stained red with safranin O (arrows), Scale bar: $500 \mu \mathrm{m}$; d histamine release in rat paw tissue at 30 min, as demonstrated by immunohistochemistry staining of histamine, the blue dye stains for the cell nucleus (white arrowheads), while the green dye stains for histamine (white arrows - diffused extracellular histamine staining), Scale bar: $1000 \mu \mathrm{m}$; e, $\mathbf{f}$ increased infiltration of ED $1^{+}$macrophages (black chevron) at 30 min as demonstrated by immunohistochemistry staining, Scale bar: $200 \mu \mathrm{m} ; \mathbf{g}-\mathbf{k}$ inflammatory gene expression at 30 min $/ 11 \beta \mathbf{g}$, $/ 16 \mathbf{h}$, Tnf $\mathbf{i}$, Cc/3 $\mathbf{j}$, and Mcp1 k; Error bars represent mean \pm SEM. ${ }^{\star} P<0.05$; ${ }^{\star \star} P<0.01$; ${ }^{\star \star \star} P<0.005$ (one-way ANOVA, Uncorrected Fisher's LSD post-hoc comparison).

8- to 9-week-old male Wistar rats $(n=27)$ were used for this experiment 
locations in health and disease, and in more chronic inflammatory diseases where mast cell turnover could be important in sustaining an inflammatory stimulus.

Historically, C3a has been thought to be formed in the liver through proteolytic cleavage of serum complement $\mathrm{C}^{36}$, but it is now emerging that many cell types, including cells of myeloid, lymphoid, and non-myeloid, non-lymphoid origin can generate C3a from transported C3 presented at the cell surface where C3 convertases are formed ${ }^{36}$. For example, activation of $\mathrm{T}$ cells induces the local expression of $\mathrm{C} 3$, factor $\mathrm{B}$ and factor $\mathrm{D}$ that results in the extracellular assembly of $\mathrm{C} 3$ convertase and cleavage to $\mathrm{C} 3 \mathrm{a}$ that acts on the cell surface $\mathrm{C}_{3} \mathrm{R}^{37}$. Rapid cleavage of the C-terminal Arg of C3a to C3a-desArg by carboxypeptidases may be an efficient defence mechanism to dampen an inflammatory response and restrict the action of $\mathrm{C} 3 \mathrm{a}$ to the cell surface. Availability of the first truly potent, stable, selective, and bioavailable C3a agonists and antagonists reported here could be valuable new molecular tools for interrogating the sequence of cellular immune responses to $\mathrm{C} 3 \mathrm{aR}$ activation in vivo in different pathological settings.

This report is the culmination of attempts to downsize the 77-residue complement C3a protein to potent and selective small molecule modulators that are stable enough to be used in vivo as chemical tools to probe C3a-dependent biology. Unlike many protein-protein interactions, the bioactive effector region of $\mathrm{C} 3 \mathrm{a}$ is localized to a small region around its C-terminal arginine. However, the C-terminal tetrapeptide segment of C3a alone has no detectable C3aR activity and it has been challenging to obtain a small molecule agonist with equal potency and functional selectivity as the C3a protein. Further, the rational development of a potent and C3aR-selective antagonist suitable for use in vivo was also a challenging goal. Here we have shown how to use different heterocycles to produce potent and selective C3aR ligands, exploiting a novel conformational switch by positioning the heterocycle adjacent to a carboxamide to change agonists into antagonists. This resulted in potent and selective agonists and antagonists that are very effective inflammatory modulators and valuable chemical biology tools when administered to rats. This approach to potent small molecule protein mimics exemplified here for one protein, might also be more generally applicable and transferable to other protein-protein interactions, where sitedirected mutagenesis has identified hot spots responsible for protein function. It remains to be determined whether this approach also leads to small molecules with similarly potent and selective functional activities and selectivity for other protein targets.

HPLC studies. Preparative-scale reversed-phase HPLC (rpHPLC) separations were performed on a Phenomenex Luna C18 $10 \mu \mathrm{m}$, $250 \times 30.0 \mathrm{~mm}$ column. Standard conditions were used for elution of all compounds: $100 \%$ A to $100 \%$ B linear gradient over $20 \mathrm{~min}$, followed by a further $10 \mathrm{~min}$ at $100 \% \mathrm{~B}$, where solvent $\mathrm{B}$ was $90 \% \mathrm{MeCN}, 10 \% \mathrm{H}_{2} \mathrm{O}+0.1 \%$ TFA, and solvent $\mathrm{A}$ was $\mathrm{H}_{2} \mathrm{O}$ $+0.1 \%$ TFA, at a flow rate of $40 \mathrm{~mL} \mathrm{~min}^{-1}$. Compounds were detected by UV spectroscopy and pure fractions were lyophilized. Analytical rpHPLC was used to assess compound purity (Phenomenex Luna C18 column, $5 \mu \mathrm{m}, 90 \AA .4 .6 \times 250 \mathrm{~mm}$, at three different wavelengths $\lambda=214,230$ and $254 \mathrm{~nm}$ ). Standard conditions (same as preparative-scale rpHPLC) were used for all compounds at a flow rate of $1 \mathrm{~mL} \mathrm{~min}{ }^{-1}$. All final compounds were $\geq 95 \%$ pure by analytical HPLC.

LCMS studies. Electrospray ionization mass spectral measurements were obtained on a Micromass LCT spectrometer. High-resolution mass spectra (HRMS) measurements were obtained on a Bruker microTOF mass spectrometer equipped with a Dionex LC system (Chromeleon) in positive ion mode by direct infusion in $\mathrm{MeCN}$ at $100 \mu \mathrm{Lh}^{-1}$ using sodium formate clusters as an internal calibrant. The data were processed using Bruker Daltonics DataAnalysis 3.4 software. Mass accuracy was consistently better than $\pm 1 \mathrm{ppm}$.

NMR studies. ${ }^{1} \mathrm{H}$ and ${ }^{13} \mathrm{C}$ NMR spectra were recorded on Bruker Avance III HD 600 equipped with a cryoprobe or Varian 400 spectrometers at $298 \mathrm{~K}$ using deuterated solvents and were referenced to the residual solvent signal DMSO- $\mathrm{d}_{6}{ }^{1} \mathrm{H} 2.50 \mathrm{ppm}$, ${ }^{13} \mathrm{C} 39.51 \mathrm{ppm} . \mathrm{CDCl}_{3}$ solutions were referenced to internal tetramethylsilane (TMS). The exact concentration of the compound for assay was confirmed by the quantitative NMR integration 'PULCON' experiment. Settings for all PULCON experiments: relaxation delay $d 1=30 \mathrm{~s}, 16$ scans, 2 dummy scans, $90^{\circ}$ pulse and temperature at $298 \mathrm{~K}$. ROESY spectra were acquired using the standard Bruker pulse sequence roesyph with a spinlock pulse of $350 \mathrm{~ms}$ and relaxation delay $2 \mathrm{~s}$.

Reagents. All reagents were purchased from Sigma-Aldrich or Chem-Impex International Inc. C3a-desArg (cat. No. C3A16-N-25) was purchased from Jomar Life Research, Australia. All compounds were synthesized via solid- or solution-phase chemistry approaches. The C5a receptor antagonist (3D53, also called PMX53 $^{16}$ is Ac-cyclo-(2,6)-Phe-[Orn-Pro-dCha-Trp-Arg], synthesized by Boc chemistry on a $0.20 \mathrm{mmol}$ scale using HBTU/DIPEA activation and in situ neutralization on Boc-L-Arg (Tos)-4-hydroxymethyl-phenylacetamidomethyl resin (PAM resin), cleavage and deprotection with $\mathrm{HF}$ and $p$-cresol $(1 \mathrm{ml})$, cyclization with BOP and DIPEA in $\mathrm{DMF}^{38}$, or it was synthesized in solution as described ${ }^{39}$.

Spectroscopic data for the characterisation of compounds 1-6. Supplementary Figs. 1-5 outline the syntheses of all compounds and full experimental details are available in the Supplementary Methods. Proton and carbon NMR spectra are shown for compounds 1-6 in Supplementary Figs. 6-17. The proton and carbon NMR data recorded on the instruments above, and the HRMS data and retention times (HPLC $t_{\mathrm{R}}$ ) measured under standard HPLC conditions, for all compounds used in this study are catalogued below.

Compound 1. ${ }^{1} \mathrm{H}$ NMR $\left(600 \mathrm{MHz}\right.$, DMSO- $\left.\mathrm{d}_{6}\right): \delta 8.28(\mathrm{~d}$, $J=8.0 \mathrm{~Hz}, 1 \mathrm{H}), 8.23(\mathrm{~s}, 1 \mathrm{H}), 7.50(\mathrm{t}, J=5.3 \mathrm{~Hz}, 1 \mathrm{H}), 7.37-7.27$ (m, 10H), $6.03(\mathrm{~s}, 1 \mathrm{H}), 4.42-4.39(\mathrm{~m}, 1 \mathrm{H}), 3.11-3.07(\mathrm{~m}, 2 \mathrm{H})$, $1.90-1.83(\mathrm{~m}, 1 \mathrm{H}), 1.81-1.74(\mathrm{~m}, 1 \mathrm{H}), 1.51-1.45(\mathrm{~m}, 2 \mathrm{H}) .{ }^{13} \mathrm{C}$ NMR $(150 \mathrm{MHz}$, DMSO-d 6 ): $\delta 173.5,173.0,160.4,156.6,149.5$, $141.8,128.7,128.67,128.66,127.3,127.2,124.9,53.6,51.6,40.3$, 28.0, 25.3. HRMS calculated for $\mathrm{C}_{23} \mathrm{H}_{26} \mathrm{~N}_{5} \mathrm{O}_{3} \mathrm{~S}^{+} 452.1751$, found 452.1750. HPLC $t_{\mathrm{R}} 14.6 \mathrm{~min}$.

Compound 2. ${ }^{1} \mathrm{H}$ NMR $\left(600 \mathrm{MHz}\right.$, DMSO- $\left.\mathrm{d}_{6}\right): \delta 8.14(\mathrm{~d}$, $J=8.0 \mathrm{~Hz}, 1 \mathrm{H}), 7.54(\mathrm{t}, J=5.7 \mathrm{~Hz}, 1 \mathrm{H}), 7.39-7.33(\mathrm{~m}, 4 \mathrm{H})$, 7.33-7.25 (m, 6H), $5.94(\mathrm{~s}, 1 \mathrm{H}), 4.39(\mathrm{~m}, 1 \mathrm{H}), 3.14-3.06(\mathrm{~m}, 2 \mathrm{H})$ $2.68(\mathrm{~s}, 3 \mathrm{H}), 1.86(\mathrm{~m}, 1 \mathrm{H}), 1.76(\mathrm{~m}, 1 \mathrm{H}), 1.53-1.43(\mathrm{~m}, 2 \mathrm{H}) .{ }^{13} \mathrm{C}$ NMR $\left(150 \mathrm{MHz}\right.$, DMSO- $\left.\mathrm{d}_{6}\right): \delta$ 173.1, 168.4, 161.8, 156.6, 142.3, $141.8,140.8,128.7,128.6,127.2,53.5,51.3,40.3,28.2,25.3,12.2$. HRMS calculated for $\mathrm{C}_{24} \mathrm{H}_{28} \mathrm{~N}_{5} \mathrm{O}_{3} \mathrm{~S}^{+} 466.1907$, found 466.1907 . HPLC $t_{\mathrm{R}} 15.4 \mathrm{~min}$.

Compound 3. (BR103) ${ }^{1} \mathrm{H}$ NMR (600 MHz, DMSO- $\left.\mathrm{d}_{6}\right): \delta 7.91$ $(\mathrm{d}, J=7.5 \mathrm{~Hz}, 1 \mathrm{H}), 7.65(\mathrm{t}, J=5.6 \mathrm{~Hz}, 1 \mathrm{H}), 7.37-7.32(\mathrm{~m}, 4 \mathrm{H})$, 7.30-7.24 (m, 6H), $5.69(\mathrm{~s}, 1 \mathrm{H}), 4.38(\mathrm{~m}, 1 \mathrm{H}), 3.16-3.05(\mathrm{~m}, 2 \mathrm{H})$, $2.41(\mathrm{~s}, 3 \mathrm{H}), 1.83(\mathrm{~m}, 1 \mathrm{H}), 1.72(\mathrm{~m}, 1 \mathrm{H}), 1.55-1.46(\mathrm{~m}, 2 \mathrm{H})$. ${ }^{13} \mathrm{C}$ NMR $\left(150 \mathrm{MHz}, \mathrm{DMSO}-\mathrm{d}_{6}\right): \delta 173.4,161.7,156.8,146.7$, $140.3,132.4,128.7,128.6,127.1,51.1,49.4,40.3,28.5,25.3,10.6$. 
HRMS calculated for $\mathrm{C}_{24} \mathrm{H}_{29} \mathrm{~N}_{6} \mathrm{O}_{3}{ }^{+} 449.2296$, found 449.2295. HPLC $t_{\mathrm{R}} 11.5 \mathrm{~min}$.

Compound 4. ${ }^{1} \mathrm{H}$ NMR $\left(600 \mathrm{MHz}\right.$, DMSO- $\left.\mathrm{d}_{6}\right): \delta 8.84(\mathrm{~d}, 1 \mathrm{H}$, $J=7.8 \mathrm{~Hz}), 8.43(\mathrm{~s}, 1 \mathrm{H}), 7.61(\mathrm{t}, 1 \mathrm{H}, J=5.5 \mathrm{~Hz}), 7.29-7.37$ $(\mathrm{m}, 10 \mathrm{H}), 6.00(\mathrm{~s}, 1 \mathrm{H}), 4.32-4.35(\mathrm{~m}, 1 \mathrm{H}), 3.08-3.15(\mathrm{~m}, 2 \mathrm{H})$, $1.82-1.88(\mathrm{~m}, 1 \mathrm{H}), 1.67-1.73(\mathrm{~m}, 1 \mathrm{H}), 1.49-1.59(\mathrm{~m}, 2 \mathrm{H})$. ${ }^{13} \mathrm{C}$ NMR $\left(150 \mathrm{MHz}, \mathrm{DMSO}-\mathrm{d}_{6}\right): \delta 176.9,173.2,160.0,156.6$, 143.9, 141.7, 134.6, 128.71, 128.67, 127.2, 53.8, 52.0, 40.3, 27.7, 25.4. HRMS: $[\mathrm{MH}]^{+}$calc. for $\mathrm{C}_{23} \mathrm{H}_{26} \mathrm{~N}_{5} \mathrm{O}_{3} \mathrm{~S}^{+}$452.1751, found 452.1751. HPLC $t_{\mathrm{R}} 14.2 \mathrm{~min}$.

Compound 5. ${ }^{1} \mathrm{H}$ NMR $\left(600 \mathrm{MHz}\right.$, DMSO- $\left.\mathrm{d}_{6}\right): \delta 8.41(\mathrm{~d}$, $J=7.8 \mathrm{~Hz}, 1 \mathrm{H}), 7.52(\mathrm{t}, J=5.6 \mathrm{~Hz}, 1 \mathrm{H}), 7.39-7.26(\mathrm{~m}, 10 \mathrm{H}), 5.94$ $(\mathrm{s}, 1 \mathrm{H}), 4.29(\mathrm{~m}, 1 \mathrm{H}), 3.13-3.04(\mathrm{~m}, 2 \mathrm{H}), 2.52(\mathrm{~s}, 3 \mathrm{H}), 1.81$ $(\mathrm{m}, 1 \mathrm{H}), 1.67(\mathrm{~m}, 1 \mathrm{H}), 1.57-1.44(\mathrm{~m}, 2 \mathrm{H}) .{ }^{13} \mathrm{C}$ NMR $(150 \mathrm{MHz}$, DMSO-d ${ }_{6}$ ): $\delta 173.1,172.6,161.4,156.6,154.9,141.7,128.7,127.2$, $125.5,53.7,52.2,40.3,27.5,25.4,17.0$. HRMS calculated for $\mathrm{C}_{24} \mathrm{H}_{28} \mathrm{~N}_{5} \mathrm{O}_{3} \mathrm{~S}^{+} 466.1907$, found 466.1907. HPLC $t_{\mathrm{R}} 14.3 \mathrm{~min}$.

Compound 6. (BR111) ${ }^{1} \mathrm{H}$ NMR $\left(600 \mathrm{MHz}, \mathrm{DMSO}-\mathrm{d}_{6}\right): \delta 8.60$ $(\mathrm{d}, J=8.0 \mathrm{~Hz}, 1 \mathrm{H}), 7.73(\mathrm{~d}, J=3.8 \mathrm{~Hz}, 1 \mathrm{H}), 7.58(\mathrm{t}, J=5.5 \mathrm{~Hz}$, $1 \mathrm{H}), 7.37-7.22(\mathrm{~m}, 11 \mathrm{H}), 6.79(\mathrm{dd}, J=3.8,1.0 \mathrm{~Hz}, 1 \mathrm{H}), 5.83(\mathrm{~s}$, $1 \mathrm{H}), 4.32(\mathrm{~m}, 1 \mathrm{H}), 3.16-3.04(\mathrm{~m}, 2 \mathrm{H}), 1.85(\mathrm{~m}, 1 \mathrm{H}), 1.70(\mathrm{~m}, 1 \mathrm{H})$, $1.61-1.46(\mathrm{~m}, 2 \mathrm{H}) .{ }^{13} \mathrm{C}$ NMR $\left(150 \mathrm{MHz}, \mathrm{DMSO}-\mathrm{d}_{6}\right): \delta 173.4$, $161.2,156.7,153.0,143.2,137.8,128.6,128.5,126.9,51.9,51.2$, 40.3, 27.7, 25.4. HRMS calculated for $\mathrm{C}_{24} \mathrm{H}_{27} \mathrm{~N}_{4} \mathrm{O}_{3} \mathrm{~S}^{+}$451.1798, found 451.1798. HPLC $t_{\mathrm{R}} 15.2 \mathrm{~min}$.

LAD2 mast cell culture and histamine assay. LAD2 human mast cells (kindly provided by Dr Dean Metcalfe, National Institute of Allergy and Infectious Diseases, National Institute of Health) were cultured in StemPro ${ }^{\circledR}$-34 Serum Free Media (Invitrogen, Australia) supplemented with StemPro ${ }^{\circledR}-34$ nutrient, $100 \mathrm{U} / \mathrm{mL}$ penicillin, $100 \mu \mathrm{g} / \mathrm{mL}$ streptomycin, $2 \mathrm{mM}$ GlutaMAX, and 100 $\mathrm{ng} / \mathrm{mL}$ human stem cell factor (SCF). Cells were hemi-depleted weekly and were not allowed to grow beyond a density of $0.5 \times 10^{6} / \mathrm{mL}$. This cell line was authenticated by expression of tryptase and histamine granules. For the histamine assay, $1 \times 10^{4}$ cells per well were seeded in StemPro ${ }^{\circledR}$-34 SFM in 96-well plates for $30 \mathrm{~min}$ before any treatments. For agonist studies, the cells were treated with compounds prepared in media for $30 \mathrm{~min}$. For antagonist studies, the cells were pre-treated with compounds prepared in SFM for $30 \mathrm{~min}$ before addition of C3aR agonists for another $30 \mathrm{~min}$. Cells were centrifuged $\left(500 \mathrm{~g}, 5 \mathrm{~min}, 4^{\circ} \mathrm{C}\right)$ and cell-free supernatants were collected for measuring histamine. Histamine content was measured using the histamine EIA kit according to the manufacturer's instructions (Abnova, Taiwan). The readings were recorded on a FLUOstar Optima (BMG LabTechnologies, Offenburg, Germany).

Isolation of primary human monocyte-derived macrophages. HMDMs were isolated using Ficoll-paque density centrifugation (GE Healthcare Bio-Science, Uppsala, Sweden) from buffy coat (of anonymous human donors) provided by the Australian Red Cross Blood Service, Brisbane. CD14 ${ }^{+}$monocytes were positively selected using CD14 MicroBeads (Miltenyi Biotech, Auburn, USA $)^{40,} 41$. CD14 ${ }^{+}$monocytes were differentiated to HMDMs using $100 \mathrm{ng} / \mathrm{mL}$ of recombinant human macrophage colonystimulating factor (PeptroTech, Rocky Hill, USA) for 7 days in Iscove's modified Dulbecco's media supplemented with $10 \%$ fetal bovine serum, penicillin $(100 \mathrm{U} / \mathrm{mL})$, streptomycin $(100 \mu \mathrm{g} / \mathrm{mL})$ and L-glutamine $(2 \mathrm{mM})$. HMDMs were supplemented after 5 days with fresh medium containing $10 \mathrm{ng} / \mathrm{ml}$ macrophage colonystimulating factor and collected by gentle scraping on day 7 .

Intracellular calcium release assay. HMDMs were seeded to a 96-well clear-bottom black-wall assay plate at a density of
$5 \times 10^{4}$ cells per well and allowed to adhere overnight. Prior to assay, cells were incubated with dye-loading buffer (Hank's balance salt solution (HBSS) buffer, $4 \mu \mathrm{M}$ Fluo-3 AM, $25 \mu \mathrm{l}$ Pluronic acid F-127 and $1 \%$ fetal bovine serum) for $1 \mathrm{~h}$ at $37^{\circ} \mathrm{C}$. Cells were then washed once with assay buffer (HBSS supplemented with $2.5 \mathrm{mM}$ probenecid and $20 \mathrm{mM}$ HEPES, $\mathrm{pH}$ 7.4). Intracellular calcium release was monitored using a fluorescence imaging plate reader (excitation $495 \mathrm{~nm}$, emission $520 \mathrm{~nm}$ ). The percentage responses were plotted against logarithmic concentrations of each test compound ${ }^{42}$.

${ }^{125} \mathrm{I}-\mathrm{C} 3 \mathrm{a}$ and ${ }^{125} \mathrm{I}-\mathrm{C} 5 \mathrm{a}$ radioligand binding assay. Receptor binding was performed by ligand competition with labelled $80 \mathrm{pM}\left[{ }^{125} \mathrm{I}\right]-\mathrm{C} 3 \mathrm{a}$ or $25 \mathrm{pM}\left[{ }^{125} \mathrm{I}\right]-\mathrm{C} 5 \mathrm{a}(2200 \mathrm{Ci} / \mathrm{mmol}$; Perkin Elmer, Torrance, CA, USA) on HMDMs $\left(1.2 \times 10^{6}\right.$ cells $\left./ \mathrm{ml}\right)$. HMDMs were treated with $\left[{ }^{125} \mathrm{I}\right]-\mathrm{C} 3 \mathrm{a}$ or $\left[{ }^{125} \mathrm{I}\right]-\mathrm{C} 5 \mathrm{a} \pm$ various concentrations of unlabelled $\mathrm{C} 3 \mathrm{a} / \mathrm{C} 5 \mathrm{a}$ or experimental ligands were diluted with assay buffer $\left(50 \mathrm{mM}\right.$ Tris, $3 \mathrm{mM} \mathrm{MgCl}_{2}$, $0.1 \mathrm{mM} \mathrm{CaCl} 2,0.5 \%(\mathrm{w} / \mathrm{v}) \mathrm{BSA}, \mathrm{pH} 7.4)$ for $60 \mathrm{~min}$ at room temperature. Unbound [ $\left.{ }^{125} \mathrm{I}\right]-\mathrm{C} 3 \mathrm{a}$ or $\left[{ }^{125} \mathrm{I}\right]-\mathrm{C} 5 \mathrm{a}$ was removed by filtration through glass microfibre filter GF/B (Whatman Iner. Ltd, England) and washed three times with cold buffer $(50 \mathrm{mM}$ Tris-HCl pH 7.4). Bound [ $\left.{ }^{125} \mathrm{I}\right]-\mathrm{C} 3 \mathrm{a}$ or $\left[{ }^{125} \mathrm{I}\right]-\mathrm{C} 5 \mathrm{a}$ were assessed by scintillation counting on Microbeta counter. Specific binding was defined as the difference between total binding and nonspecific binding as determined in the presence of $1 \mu \mathrm{M}$ unlabelled C3a or $\mathrm{C} 5 \mathrm{a}^{4}$.

Europium (Eu)-C3a competitive binding assay. HEK293 $\mathrm{G}_{16}$-C3aR cells were non-enzymatically lifted using Versene Solution and seeded at 30,000 cells per well in 2\% BSA in phosphate buffered saline (PBS) in a round-bottom 96-well plate. Cells were simultaneously treated with Eu-DTPA-C3a $(2 \mathrm{nM})$ and various concentrations of $\mathrm{C} 3 \mathrm{a}$ or $\mathrm{C} 3 \mathrm{a}$-desArg for $60 \mathrm{~min}$ at room temperature with shaking. Cells were then washed thrice with PBS supplemented with $0.2 \%$ BSA, $20 \mu \mathrm{M}$ EDTA and $0.01 \%$ Tween-20 by repeated centrifugation. Cells were then resuspended with $20 \mu \mathrm{L}$ of DELFIA enhancement solution (PerkinElmer) and then transferred to a white 384-well ProxiPlate (PerkinElmer). Time-resolved fluorescence was measured using a PHERAstar plate reader (BMG Labtech) at $337 \mathrm{~nm}$ excitation followed by $400 \mu$ s delay before $620 \mathrm{~nm}$ emission.

Immunobloting. Human Embryonic Kidney (HEK) 293 cells (ATCC, USA) and HMDMs were lysed on ice. Equal amounts of cell lysates were separated, transferred using iBlot Dry Blotting System (Invitrogen). Human $\mathrm{C} 3 \mathrm{aR}$ was detected with mouse monoclonal $\operatorname{IgG}_{2 \mathrm{a}}$ (Santa Cruz Biotechnology, SC-133172, 1:200) and secondary HRP-linked anti-mouse IgG (Cell Signaling Technology, \#7076, 1:500). GAPDH was detected using affinity isolated rabbit anti-GAPDH (Sigma-Aldrich, G9545, 1:10,000) and secondary HRP-linked anti-rabbit IgG (Cell Signaling Technology, \#7074, 1:10,000). An example of a full blot is shown in Supplementary Fig. 18.

Plasma and metabolic stability. For plasma stability studies, C3a and experimental compounds ( $10 \mu \mathrm{L}, 1 \mathrm{mM}$ in DMSO) were added to neat rat plasma $(190 \mu \mathrm{L})$ and heated to $37^{\circ} \mathrm{C}$ in a circulating water bath. Aliquots $(20 \mu \mathrm{L})$ were collected at time points $(0,2,5$ and $10 \mathrm{~min}$ for C3a; $0,5,15,30,60,120$ and 240 min for other test compounds) and added directly to $\mathrm{MeCN} / \mathrm{H}_{2} \mathrm{O}(80 \mu \mathrm{L}$, 9:1). The samples were centrifuged at $13,000 \mathrm{~g}$ for $3 \mathrm{~min}$ before supernatants were isolated and analyzed for test compound degradation via LC-MS. For liver microsomal stability studies, commercially available rat liver microsomes from Life 
Technologies, GIBCO were used. In brief, microsomes stored at $-80{ }^{\circ} \mathrm{C}$ were slowly defrosted on ice. Test compounds $(183 \mu \mathrm{L}, 1$ $\mu \mathrm{M}$ in $100 \mathrm{mM}$ phosphate buffer $\mathrm{pH} 7.4$ containing $0.1 \%$ DMSO) were added to microsomes $(5 \mu \mathrm{L})$ and NADPH $(2 \mu \mathrm{L}, 20 \mathrm{mM})$. Test solutions were heated in a circulating water bath at $37^{\circ} \mathrm{C}$ for $5 \mathrm{~min}$ before additional cofactor NADPH $(10 \mu \mathrm{L}, 20 \mathrm{mM})$ was added. Aliquots $(20 \mu \mathrm{L})$ were taken at time points $(0,5,15,30$ and $60 \mathrm{~min}$ from the second addition of $\mathrm{NADPH})$. Aliquots were added to $\mathrm{MeCN} / \mathrm{H}_{2} \mathrm{O}(80 \mu \mathrm{L}, 9: 1)$ and centrifuged at $13,000 \mathrm{~g}$ for $3 \mathrm{~min}$. Supernatants were analyzed for test compound degradation by LC-MSMS. Concentrations were plotted as a function of time on a semi-logarithmic graph. Rat plasma and microsomal activity was confirmed by rapid degradation of SLIGRL- $\mathrm{NH}_{2}\left(\mathrm{t}_{1 / 2}<5 \mathrm{~min}\right)$ in a parallel experiment.

Animals. All experiments were approved by the Molecular Biosciences Animal Ethics Committee of The University of Queensland, and adhere to The Australian Code of Practice for Use Of Animals for Scientific Purposes (2013) and The Australian Government Guidelines to Promote the Wellbeing of Animals used For Scientific Purposes (2013). Studies involving animals are reported in accordance with the ARRIVE guidelines ${ }^{43}$. A total of 109 animals were used in the experiments described here. Numbers were determined using power analysis (Effect size; 0.25, Power 0.8. G*Power 3.1.9) Male Wistar rats (8-9 weeks, $250 \pm 20 \mathrm{~g}$ ) were bred at the Australia Animal Resource Centre (Canning Vale, WA, Australia). Animals were housed in the appropriate temperature/pressure environment in a $12 \mathrm{~h}$ light/ dark cycle, according to the standards of the accredited holding facility, with food and water provided ad libitum. At least $48 \mathrm{~h}$ habituation in the UQBR facility was provided prior to any experimental intervention. After experimentation, animals were humanely killed by $\mathrm{CO}_{2}$ inhalation as stipulated by approved ethical agreements.

Rat paw edema. Male Wistar rats (8-9 weeks) were injected with $\operatorname{BR} 103(3,350 \mu \mathrm{g}$ in $100 \mu \mathrm{L}$ isotonic saline) into the plantar surface of both hind paw pads using a $30 \mathrm{G}$ needle. The inhibitor cromolyn $(20 \mathrm{mg} / \mathrm{kg}$ in $5 \%$ DMSO $)$ was injected subcutaneously $30 \mathrm{~min}$ before the agonist. The antagonist BR111 (6, 5-20 mg/kg in olive oil) was administered orally as a single dose $2 \mathrm{~h}$ before the agonist. Paw thickness and width were measured using digital calipers (WPI) at $0,0.5,2,6$ and $24 \mathrm{~h}$ after agonist BR103 administration. Hind paw size is expressed as \% change in area from baseline after $0.5 \mathrm{~h}$ and then normalized against maximum swelling induced by agonist alone. Researchers were not blinded to treatments given.

Histopathology and immunohistochemistry. Rat paw tissue was collected and fixed in $4 \%$ paraformaldehyde ( $\mathrm{pH} \mathrm{7.4)}$ for $2 \mathrm{~h}$ in the cold room $\left(4^{\circ} \mathrm{C}\right)$. The rat paw tissue was then transferred into falcon tubes containing 30\% sucrose solution in PBS and left overnight in the cold room. The next day, rat paw tissue was embedded with the Optimal Cutting Temperature compound (OCT, Sakura Finetek, USA) and stored in the $-80^{\circ} \mathrm{C}$ freezer before being used for making cryo-sections for histological analysis. Frozen sections of 5 microns were prepared using a cryostat-microtome (Leica Biosystems, Germany) and stained using standard protocols on the same day. In normal histological staining, such as with alcian blue and safranin $\mathrm{O}$ and hematoxylin and eosin $(\mathrm{H} \& \mathrm{E})$, samples were briefly washed with distilled water before staining. In alcian blue and safranin $\mathrm{O}$, samples were stained with $0.1 \%$ alcian blue (Sigma-Aldrich, USA) and $0.5 \%$ safranin O (Sigma-Aldrich, USA) before being mounted in mounting medium. In $\mathrm{H} \& \mathrm{E}$, samples were stained with hematoxylin (Sigma-Aldrich, USA) and $0.1 \%$ eosin (SigmaAldrich, USA) before being mounted in mounting medium. In immunohistochemistry, samples were briefly rinsed with PBS to remove OCT and incubated with blocking medium (PBS, $0.1 \%$ triton $\mathrm{X}-100,10 \%$ horse serum) for $1 \mathrm{~h}$ at room temperature. Samples were incubated with primary antibody medium (PBS, $4 \%$ horse serum, 1:200 histamine or 1:200 of tryptase or 1:150 ED1 or 1:200 ED2 antibodies) overnight at $4{ }^{\circ} \mathrm{C}$. The next day, samples were washed with PBS and were incubated with the secondary antibody medium (PBS, 4\% horse serum, detection antibody 1:1000) for $1 \mathrm{~h}$ at room temperature. The samples were briefly rinsed, dried and counterstained with DAPI (Invitrogen, Australia). Primary antibodies for histamine (Sigma-Aldrich, USA, H2403, monoclonal rabbit anti-rat IgG, 1: 200), tryptase (Abcam, Australia, ab2378, monoclonal mouse anti-rat IgG, 1:200), ED1 (Serotec, UK, MCA341R, monoclonal mouse anti-rat, 1:150), ED2 (Serotec, UK, MCA3424R, monoclonal mouse anti-rat, 1:200) were purchased from commercial sources. Secondary detection antibody was purchased from (Invitrogen, Australia). ED1 \& ED2 positive cells were quantified using FIJI/ImageJ 1.42q software, U.S. National Institutes of Health, Bethesda, MD, $\mathrm{USA}^{44}$. All microscope images were obtained using an Olympus BX-51 upright microscope with Olympus DP-71 12Mp colour camera, utilizing DP Capture and DP Manager software packages (Olympus, Tokyo, Japan). Researchers who performed histological analysis and scoring were blinded to the sample identity.

Myeloperoxidase assay. Rat paw tissues were collected and immediately frozen with liquid nitrogen. The frozen rat paw tissue samples were weighed and crushed into smaller pieces with a mortar and pestle in liquid nitrogen. The crushed tissues were added to MPO buffer $(50 \mathrm{mM}$ potassium phosphate buffer, $\mathrm{pH}$ 6.0) to make up a concentration of $200 \mathrm{mg} / \mathrm{mL}$ and homogenized using Zirconium oxide beads (Next Advance, USA) and the Bullet Blender ${ }^{\circledR}$ homogeniser (Next Advance, USA). The homogenized tissues were then diluted to $100 \mathrm{mg} / \mathrm{mL}$ with the MPO buffer containing $1 \%$ hexadecyl trimethylamonium bromide (SigmaAldrich, USA) and underwent three cycles of freeze, thaw, and sonication. The samples were centrifuged at $13,000 \mathrm{~g}$ for $10 \mathrm{~min}$ at $4{ }^{\circ} \mathrm{C}$ and the clear supernatant for each samples were collected. To measure the MPO release, $10 \mu \mathrm{L}$ of the sample supernatant was added with $290 \mu \mathrm{L}$ of substrate solution (MPO buffer, $0.167 \mathrm{mg} / \mathrm{mL}$ o-dianisidine. $\mathrm{HCl}, 0.001 \% \mathrm{H}_{2} \mathrm{O}_{2}$ ) in a clear 96-well plate. The plate was read immediately at $460 \mathrm{~nm}$ every min for 20 min using a plate reader (PHERAstar FS, BMG Labtech, Germany). O-dianisidine $\mathrm{HCl}$ was purchased from Sigma-Aldrich (USA).

RNA isolation and gene analysis. Rat paw tissues were collected and immediately frozen with liquid nitrogen. Frozen rat paw tissues were cut into smaller pieces and mixed with $1 \mathrm{~mL}$ of TRIsure (Bioline, Australia) prior to homogenizing according to manufacturer's instructions. Homogenized tissue samples were added with $200 \mu \mathrm{L}$ of chloroform and mixed thoroughly. The samples were centrifuged at $11,000 \mathrm{~g}$ for $15 \mathrm{~min}$. The top clear solution for each sample was collected and isolated using the ISOLATE II RNA Mini Kit (Bioline, Australia) according to the manufacturer's instructions. RNA was converted to cDNA using SuperScript ${ }^{\circledR}$ III Reverse Transcriptase (Invitrogen, Australia) and Oligo(dT)12-18 primer (Invitrogen, Australia) according to manufacturer's instructions. Real-time PCR was measured on a ABI PRISM 7900HT (Applied Biosystems), each target gene was normalized to housekeeping $18 \mathrm{~S}$ rRNA and fold change was calculated relative to control sample (Sham). All samples were done in duplicates. Primer sequences (Supplementary Table 1) were designed using the Primer-Blast online-based software. 
Statistical analysis. All experimental results are expressed as means \pm standard error. The data were plotted and analyzed using GraphPad Prism version 5.0c for Mac OS X (GraphPad Software). Statistically significant differences were assessed either using student's $t$-test for paired comparison or a two-way repeated measures ANOVA as appropriate. All values of independent parameters are shown as mean \pm SEM of at least three independent experiments, unless otherwise stated. Significance was set at ${ }^{\star} P<0.05,{ }^{\star *} P<0.01$ and ${ }^{\star *} P<0.001$.

Data availability. The data that support the findings of this study are available from the corresponding author upon reasonable request.

Received: 18 January 2017 Accepted: 28 June 2017

Published online: 24 August 2017

\section{References}

1. Scott, D. E., Bayly, A. R., Abell, C. \& Skidmore, J. Small molecules, big targets: drug discovery faces the protein-protein interaction challenge. Nat. Rev. Drug. Discov. 15, 533-50 (2016).

2. Modell, A. E., Blosser, S. L. \& Arora, P. S. Systematic targeting of proteinprotein interactions. Trends. Pharmacol. Sci. 37, 702-13 (2016).

3. Mullard, A. Protein-protein interaction inhibitors get into the groove. Nat. Rev. Drug Discov. 11, 173-5 (2012).

4. Reid, R. C. et al. Downsizing a human inflammatory protein to a small molecule with equal potency and functionality. Nat. Commun. 4, 2802 (2013).

5. Masters, S. L., Simon, A., Aksentijevich, I. \& Kastner, D. L. Horror autoinflammaticus: the molecular pathophysiology of autoinflammatory disease. Annu. Rev. Immunol. 27, 621-68 (2009).

6. Zipfel, P. F. \& Skerka, C. Complement regulators and inhibitory proteins. Nat. Rev. Immunol. 9, 729-40 (2009).

7. Strainic, M. G., Shevach, E. M., An, F., Lin, F. \& Medof, M. E. Absence of signaling into $\mathrm{CD} 4(+)$ cells via $\mathrm{C} 3 \mathrm{aR}$ and $\mathrm{C} 5 \mathrm{aR}$ enables autoinductive TGF-betal signaling and induction of Foxp3(+) regulatory T cells. Nat. Immunol. 14, 162-71 (2013).

8. Proctor, L. M. et al. Complement factors C3a and C5a have distinct hemodynamic effects in the rat. Int. Immunopharmacol. 9, 800-6 (2009).

9. Gerard, N. P. \& Gerard, C. Complement in allergy and asthma. Curr. Opin. Immunol. 14, 705-8 (2002).

10. Mizutani, N., Nabe, T. \& Yoshino, S. Complement C3a regulates late asthmatic response and airway hyperresponsiveness in mice. J. Immunol. 183, 4039-46 (2009).

11. Hutamekalin, P. et al. Effect of the C3a-receptor antagonist SB 290157 on anti-OVA polyclonal antibody-induced arthritis. J. Pharmacol. Sci. 112, 56-63 (2010).

12. Kildsgaard, J. et al. Cutting edge: targeted disruption of the C3a receptor gene demonstrates a novel protective anti-inflammatory role for $\mathrm{C} 3 \mathrm{a}$ in endotoxinshock. J. Immunol. 165, 5406-9 (2000).

13. Jacob, A., Bao, L., Brorson, J., Quigg, R. J. \& Alexander, J. J. C3aR inhibition reduces neurodegeneration in experimental lupus. Lupus 19, 73-82 (2010).

14. Mamane, Y. et al. The C3a anaphylatoxin receptor is a key mediator of insulin resistance and functions by modulating adipose tissue macrophage infiltration and activation. Diabetes 58, 2006-17 (2009).

15. Proctor, L. M. et al. Comparative anti-inflammatory activities of antagonists to C3a and C5a receptors in a rat model of intestinal ischaemia/reperfusion injury. Br. J. Pharmacol. 142, 756-64 (2004).

16. Lim, J. et al. C5aR and $\mathrm{C} 3 \mathrm{aR}$ antagonists each inhibit diet-induced obesity, metabolic dysfunction, and adipocyte and macrophage signaling. FASEB J. 27, 822-31 (2013).

17. Pasupuleti, M. et al. Preservation of antimicrobial properties of complement peptide C3a, from invertebrates to humans. J. Biol. Chem. 282, 2520-2528 (2007).

18. Ames, R. S. et al. Identification of a selective nonpeptide antagonist of the anaphylatoxin $\mathrm{C} 3 \mathrm{a}$ receptor that demonstrates antiinflammatory activity in animal models. J. Immunol. 166, 6341-6348 (2001).

19. Reid, R. C. et al. Potent heterocyclic ligands for human complement C3a receptor. J. Med. Chem. 57, 8459-70 (2014).

20. Reid, R. C., Yau, M. K., Singh, R., Lim, J. \& Fairlie, D. P. Stereoelectronic effects dictate molecular conformation and biological function of heterocyclic amides. J. Am. Chem. Soc. 136, 11914-11917 (2014).
21. Kubota, Y. The effect of human anaphylatoxins and neutrophils on histamine release from isolated human skin mast cells. J. Dermatol. 19, 19-26 (1992).

22. Beno, B. R., Yeung, K. S., Bartberger, M. D., Pennington, L. D. \& Meanwell, N. A. A survey of the role of noncovalent sulfur interactions in drug design. J. Med. Chem. 58, 4383-438 (2015).

23. Crass, T. et al. Expression cloning of the human $\mathrm{C} 3 \mathrm{a}$ anaphylatoxin receptor (C3aR) from differentiated U-937 cells. Eur. J. Immunol. 26, 1944-50 (1996).

24. Atwood, N. K., Lopez, J., Wager-Miller, J., Mackie, K. \& Straiker, A. Expression of $\mathrm{G}$ protein-coupled receptors and related proteins in HEK293, AtT20, BV2, and N18 cell lines as revealed by microarray analysis. BMC Genomics. 12, 14 (2011).

25. Insel, P. A. et al. G Protein-Coupled Receptor (GPCR) expression in native cells: "novel" endoGPCRs as physiologic regulators and therapeutic targets. Mol. Pharmacol. 88, 181-187 (2015).

26. Bokisch, V. A. \& Muller-Eberhard, H. J. Anaphylatoxin inactivator of human plasma: its isolation and characterization as a carboxypeptidase. J. Clin. Invest. 49, 2427-36 (1970).

27. Morris, C. J. Carrageenan-induced paw edema in the rat and mouse. Methods Mol. Biol. 225, 115-21 (2003).

28. Rodewald, H. R. \& Feyerabend, T. B. Widespread immunological functions of mast cells: fact or fiction? Immunity 37, 13-24 (2012).

29. Voehringer, D. Protective and pathological roles of mast cells and basophils. Nat. Rev. Immunol. 13, 362-75 (2013).

30. Wernersson, S. \& Pejler, G. Mast cell secretory granules: armed for battle. Nat. Rev. Immunol. 14, 478-94 (2014).

31. Theoharides, T. C., Valent, P. \& Akin, C. Mast cells, mastocytosis, and related disorders. N. Engl. J. Med. 373, 163-72 (2015).

32. Theoharides, T. C. \& Stewart, J. M. Genitourinary mast cells and survival. Transl Androl Urol 4, 579-86 (2015).

33. Bischoff, S. C. Role of mast cells in allergic and non-allergic immune responses: comparison of human and murine data. Nat. Rev. Immunol. 7, 93-104 (2007).

34. Sarrazin, S. \& Sieweke, M. H. Eosinophils and mast cells: a lineage apart. Nat Immunol. 17, 609-11 (2016).

35. Dwyer, D. F., Barrett, N. A. \& Austen, K. F., Immunological Genome Project, C. Expression profiling of constitutive mast cells reveals a unique identity within the immune system. Nat. Immunol. 17, 878-87 (2016).

36. Minton, K. Innate immunity: the inside story on complement activation. Nat. Rev. Immunol. 14, 61 (2014).

37. Liszewski, M. K. et al. Intracellular complement activation sustains T cell homeostasis and mediates effector differentiation. Immunity 39, 1143-57 (2013).

38. March, D. R. et al. Potent cyclic antagonists of the complement C5a receptor on human polymorphonuclear leukocytes. Relationships between structures and activity. Mol. Pharmacol. 65, 868-79 (2004).

39. Reid, R. C., Abbenante, G., Taylor, S. M. \& Fairlie, D. P. A convergent solution-phase synthesis of the macrocycle Ac-Phe-[Orn-Pro-D-Cha-Trp-Arg], a potent new antiinflammatory drug. J. Org. Chem. 68, 4464-71 (2003).

40. Ariffin, J. K. et al. Histone deacetylase inhibitors promote mitochondrial reactive oxygen species production and bacterial clearance by human macrophages. Antimicrob. Agents Chemother. 60, 1521-1529 (2016).

41. Seow, V. et al. Inflammatory responses induced by lipopolysaccharide are amplified in primary human monocytes but suppressed in macrophages by complement protein C5a. J. Immunol. 191, 4308-16 (2013).

42. Lim, J. et al. Diet-induced obesity, adipose inflammation, and metabolic dysfunction correlating with PAR2 expression are attenuated by PAR2 antagonism. FASEB J. 27, 4757-67 (2013).

43. Kilkenny, C., Browne, W., Cuthill, I. C., Emerson, M. \& Altman, D. G. NC3Rs reporting guidelines working group. animal research: reporting in vivo experiments: the ARRIVE guidelines. Br. J. Pharmacol. 160, 1577-79 (2010).

44. Lohman, R. J. et al. Differential anti-inflammatory activity of HDAC inhibitors in human macrophages and rat arthritis. J. Pharmacol. Exp. Ther. 356, 387-96 (2016).

\section{Acknowledgements}

This research was supported by the National Health and Medical Research Council (grants 1084018, 1028423, Senior Principal Research Fellowships 1027369, 1117017 to DPF), the Australian Research Council (grant DP130100629), the Australian Research Council Centre of Excellence in Advanced Molecular Imaging (CE140100011), and the Queensland Government (CIF grant). We thank the University of Queensland for PhD scholarships to J.K.H., M.-K.Y., J.A.R. and D.S.N., and a UQ Postdoctoral Research Fellowship to A.I. We thank Dr Dean Metcalfe (National Institute of Allergy and Infectious Diseases, National Institute of Health) for kindly providing LAD2 mast cells, the Australian Red Cross (Brisbane) for generously providing buffy coats, the Australian Cancer Research Foundation and Cancer Biology Imaging Facility for the use of bright field and fluorescence microscopes.

\section{Author contributions}

A.I. and D.P.F. led the study, analyzed all the data and wrote the manuscript. R.-J.L. performed all in vivo and ex vivo rat studies with help from J.K.H., A.D. and A.I. 
Compounds were designed, synthesized, and characterized by R.C.R., M.-K.Y., J.A.R. and D.P.F., including analysis of ligand conformations by $2 \mathrm{D}$ NMR spectroscopy. J.K.H. and A.I. performed in vitro experiments on mast cells, macrophages and ex vivo on rat paw tissues. M.A.H. conducted in vitro experiments on mast cells. M.K.Y. performed in vitro experiments on macrophages. J.L., Z.L. and K.-C.W. performed in vitro experiments on HEK293 cells. D.S.N. performed ex vivo metabolic stability experiments. J.Y.S. analyzed the data from in vitro experiments on mast cells and macrophages. All authors approved the final manuscript.

\section{Additional information}

Supplementary Information accompanies this paper at doi:10.1038/s41467-017-00414-w.

Competing interests: M.-K.Y., R.C.R., and D.P.F. are named inventors on a patent application (US14356,821), involving complement C3a receptor agonists and antagonists, that is owned by the University of Queensland. The remaining authors declare no competing financial interests.

Reprints and permission information is available online at http://npg.nature.com/ reprintsandpermissions/
Publisher's note: Springer Nature remains neutral with regard to jurisdictional claims in published maps and institutional affiliations.

(c) (i) Open Access This article is licensed under a Creative Commons Attribution 4.0 International License, which permits use, sharing, adaptation, distribution and reproduction in any medium or format, as long as you give appropriate credit to the original author(s) and the source, provide a link to the Creative Commons license, and indicate if changes were made. The images or other third party material in this article are included in the article's Creative Commons license, unless indicated otherwise in a credit line to the material. If material is not included in the article's Creative Commons license and your intended use is not permitted by statutory regulation or exceeds the permitted use, you will need to obtain permission directly from the copyright holder. To view a copy of this license, visit http://creativecommons.org/ licenses/by/4.0/.

(C) The Author(s) 2017 